\title{
Contrasting winter and summer VOC mixing ratios at a forest site in the Western Mediterranean Basin: the effect of local biogenic emissions
}

\author{
R. Seco ${ }^{1, *}$, J. Peñuelas ${ }^{1}$, I. Filella ${ }^{1}$, J. Llusià ${ }^{1}$, R. Molowny-Horas ${ }^{2}$, S. Schallhart ${ }^{3,{ }^{* *}}$, A. Metzger ${ }^{4}$, M. Müller ${ }^{3, * * *}$, and \\ A. Hansel ${ }^{3}$ \\ ${ }^{1}$ Unitat d'Ecologia Global CREAF-CEAB-CSIC, Centre de Recerca Ecològica i Aplicacions Forestals (CREAF), \\ Universitat Autònoma de Barcelona, 08193 Bellaterra (Barcelona), Catalunya, Spain \\ ${ }^{2}$ Centre de Recerca Ecològica i Aplicacions Forestals (CREAF), Universitat Autònoma de Barcelona, \\ 08193 Bellaterra (Barcelona), Catalunya, Spain \\ ${ }^{3}$ Institut für Ionenphysik und Angewandte Physik, Universität Innsbruck, Technikerstrasse 25, 6020 Innsbruck, Austria \\ ${ }^{4}$ Ionicon Analytik, Eduard-Bodemgasse 3, 6020 Innsbruck, Austria \\ *now at: Atmospheric Chemistry Division, National Center for Atmospheric Research, Boulder, CO 80301, USA \\ ** now at: Department of Physical Sciences, Division of Atmospheric Sciences P.O. Box 64, Gustaf Hällströminkatu 2, \\ 00014 University of Helsinki, Finland \\ *** now at: DBFZ Deutsches BiomasseForschungsZentrum gemeinnützige GmbH, Torgauer Straße 116, \\ 04347 Leipzig, Germany
}

Received: 17 May 2011 - Published in Atmos. Chem. Phys. Discuss.: 19 July 2011

Revised: 10 November 2011 - Accepted: 8 December 2011 - Published: 21 December 2011

\begin{abstract}
Atmospheric volatile organic compounds (VOCs) are involved in ozone and aerosol generation, thus having implications for air quality and climate. VOCs and their emissions by vegetation also have important ecological roles as they can protect plants from stresses and act as communication cues between plants and between plants and animals. In spite of these key environmental and biological roles, the reports on seasonal and daily VOC mixing ratios in the literature for Mediterranean natural environments are scarce.

We conducted seasonal (winter and summer) measurements of VOC mixing ratios in an elevated (720 ma.s.1.) holm oak Mediterranean forest site near the metropolitan area of Barcelona (NE Iberian Peninsula). Methanol was the most abundant compound among all the VOCs measured in both seasons. While aromatic VOCs showed almost no seasonal variability, short-chain oxygenated VOCs presented higher mixing ratios in summer, presumably due to greater emission by vegetation and increased photochemistry, both enhanced by the high temperatures and solar radiation in summer. Isoprenoid VOCs showed the biggest seasonal change in mixing ratios: they increased by one order of magnitude in summer, as a result of the vegetation's
\end{abstract}

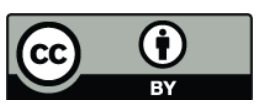

Correspondence to: R. Seco

(roger@creaf.uab.cat) greater physiological activity and emission rates. The maximum diurnal concentrations of ozone increased in summer too, most likely due to more intense photochemical activity and the higher levels of VOCs in the air.

The daily variation of VOC mixing ratios was mainly governed by the wind regime of the mountain, as the majority of the VOC species analyzed followed a very similar diel cycle. Mountain and sea breezes that develop after sunrise advect polluted air masses to the mountain. These polluted air masses had previously passed over the urban and industrial areas surrounding the Barcelona metropolitan area, where they were enriched in $\mathrm{NO}_{\mathrm{x}}$ and in VOCs of biotic and abiotic origin. Moreover, these polluted air masses receive additional biogenic VOCs emitted in the local valley by the vegetation, thus enhancing $\mathrm{O}_{3}$ formation in this forested site. The only VOC species that showed a somewhat different daily pattern were monoterpenes because of their local biogenic emission. Isoprene also followed in part the daily pattern of monoterpenes, but only in summer when its biotic sources were stronger. The increase by one order of magnitude in the concentrations of these volatile isoprenoids highlights the importance of local biogenic summer emissions in these Mediterranean forested areas which also receive polluted air masses from nearby or distant anthropic sources.

Published by Copernicus Publications on behalf of the European Geosciences Union. 


\section{Introduction}

Volatile organic compounds (VOCs) present in the atmosphere have both natural and anthropogenic sources. Among the natural origins, emission by vegetation is regarded as the greatest source at a global scale (Guenther et al., 2006). VOCs play several key roles in atmospheric chemistry which make them highly relevant for study, for example their implication in tropospheric ozone and aerosol generation. VOCs, together with nitrogen oxides $\left(\mathrm{NO}_{\mathrm{x}}\right)$ and solar radiation are the ingredients needed to promote the photochemical formation of tropospheric ozone (Atkinson, 2000; Sillman, 1999). Ozone is an oxidant pollutant that has negative effects on plants (Fowler et al., 2009), poses a threat to human health (Lippmann, 1993) and acts in the troposphere as a greenhouse gas. VOCs are also precursors of atmospheric aerosols (Kavouras et al., 1998; Tunved et al., 2006), which can have significant climate implications (Kulmala et al., 2004; Pacifico et al., 2009). In a context of global change, the relationships between VOCs, particles and ozone are a hot topic in current scientific research (Peñuelas and Staudt, 2010). They all are involved in biogeochemical cycles and take part with other global change drivers in complex feedbacks with the climate (Arneth et al., 2010). Atmospheric VOCs and their emissions by vegetation are also ecologically important because VOCs can protect plants against high temperatures (Peñuelas et al., 2005; Singsaas and Sharkey, 1998), high irradiance (Peñuelas and Munné-Bosch, 2005), and oxidative stress (Peñuelas and Llusià, 2002, Velikova et al., 2005). In addition, they also act as plant-plant communication signals (Baldwin et al., 2006; Kegge and Pierik, 2010; Peñuelas et al., 1995; Seco et al., 2011). Likewise, VOCs play a role in plant-animal relationships, not only involving plant-pollinator relationships (Wright and Schiestl, 2009) or direct defense against herbivores, but also indirect defense through the attraction of the natural enemies of the herbivores (Kessler and Baldwin, 2001; Llusià and Peñuelas, 2001).

In the Mediterranean area, where the potential for biogenic VOC emissions and photochemistry is high, ozone and particle formation can be elevated and the ecological role of VOCs can be very significant. However, there is scarce information on tropospheric VOC mixing ratios in the Mediterranean region. Ozone has been measured in high concentrations in the Mediterranean area (Gimeno et al., 1995; Ribas and Peñuelas, 2004; Ziomas, 1998), and has already been reported to produce damage to plants in the Western Mediterranean Basin (Ribas et al., 2005; Sanz et al., 2000). Moreover, ozone concentrations have been found to increase with altitude (Diaz-de-Quijano et al., 2009; Evtyugina et al., 2009; Ribas and Peñuelas, 2006).

In recent years, the proton transfer reaction mass spectrometer (PTR-MS) has enabled the simultaneous measuring of several VOCs, including some oxygenated VOCs that are difficult to measure with other techniques (Seco et al., 2007, 2008). Also, PTR-MS has improved the temporal resolu- tion of these measurements, to the point of making the use of micrometeorological techniques possible (Karl et al., 2001). Of late, papers have reported several concomitant surfacelevel VOC mixing ratios in natural areas, taking advantage of the PTR-MS technology in boreal and temperate regions (e.g. Holst et al., 2010; Jordan et al., 2009; Lappalainen et al., 2009; Ruuskanen et al., 2009; Spirig et al., 2005). Nevertheless, there are few studies dealing with Mediterranean ecosystems (e.g. Davison et al., 2009).

In this paper we report VOC data gathered during 2009 in an elevated site highly representative of the montane Mediterranean forest (Terradas, 1999), located in a forested mountain slope, in the Western Mediterranean Basin. We compared the VOC mixing ratios between winter (FebruaryMarch) and summer (July-August), and analysed their relationship with meteorological data, and with ozone $\left(\mathrm{O}_{3}\right)$ and nitrogen oxides $\left(\mathrm{NO}_{\mathrm{x}}\right.$, i.e. $\mathrm{NO}$ and $\left.\mathrm{NO}_{2}\right)$ concentrations. We also compared the VOC mixing ratio values and daily trends at this Montseny (MSY) site with those reported in the existing literature for other natural areas worldwide.

\section{Methods}

\subsection{Measurement site}

The Montseny site (MSY) was located within a densely forested natural park about $50 \mathrm{~km}$ to the NNE of the city of Barcelona (Catalonia, NE of the Iberian peninsula) and $25 \mathrm{~km}$ from the Mediterranean coast $\left(41^{\circ} 46^{\prime} 45.63^{\prime \prime} \mathrm{N}\right.$ $02^{\circ} 21^{\prime} 28.92^{\prime \prime}$ E, $720 \mathrm{~m}$ a.s.l.; Fig. 1). The site is highly representative of the montane holm oak (Quercus ilex L.) forests in the Mediterranean regions of France, Italy, Greece and eastern Spain (Terradas, 1999). At Montseny, these are dense forests of resprout origin, which evolved from coppicing until the 1950s and selection thinning afterwards (Avila and Rodrigo, 2004).

To our knowledge, this was the first time that VOC mixing ratios were measured continuously over several days at this Mediterranean forest location, which has a long record of other ecological and biogeochemical parameters such as nutrient cycling (Avila et al., 2002), dry and wet deposition (Avila et al., 1998, 2007, 2010; Avila and Rodà, 2002; Avila and Alarcon, 2003), hydrology (Piñol et al., 1992), and particulate matter (Pey et al., 2009; Pérez et al., 2008), among others.

\subsection{VOC measurements}

VOC measurements were conducted with two different Proton Transfer Reaction-Mass Spectrometers (PTR-MS), one for each season, installed in an uninhabited traditional rural house (La Castanya). The house is situated in a forest clearing in a south-facing slope of the mountain, surrounded by the holm oak forest. Both PTR-MS set-ups sampled ambient 

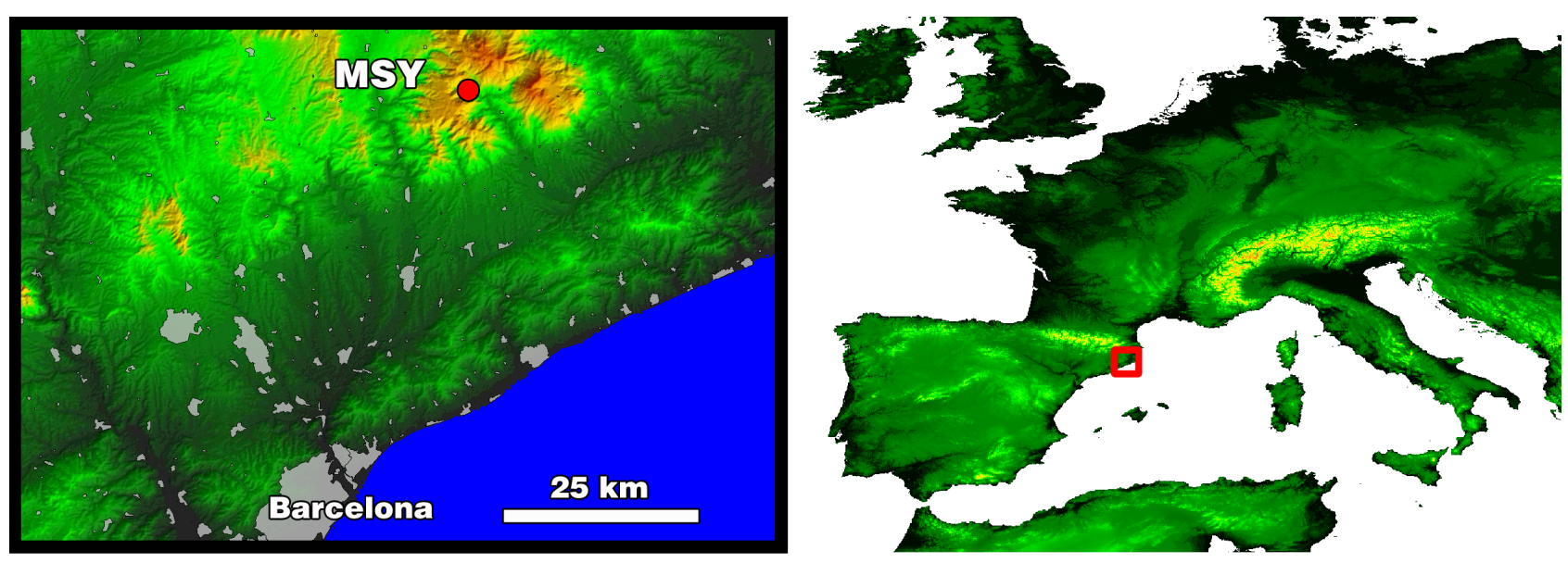

Fig. 1. Location of the Montseny (MSY) measurement site, in relation to the city of Barcelona.

Table 1. Masses measured with the different PTR-MS systems and the corresponding VOC identity assigned to them. The mean sensitivity and the limit of detection for each VOC are also displayed. Sensitivities shown are transmission corrected and normalized to the primary ion signal, taking into account all major molecular fragments. Detection limits (DL) were inferred from a signal to noise ratio (S/N) of 2 according to $\mathrm{DL}=2 \times \mathrm{SD}_{\text {blank }} /$ sensitivity, with $\mathrm{SD}_{\text {blank }}$ being the standard deviation of background countrates, as reported elsewhere (Karl et al., 2003).

\begin{tabular}{|c|c|c|c|c|c|c|}
\hline \multirow[b]{2}{*}{$\begin{array}{l}\text { Assigned VOC } \\
\text { identity }\end{array}$} & \multicolumn{3}{|c|}{ PTR-ToF-MS (winter) } & \multicolumn{3}{|c|}{ PTR-Quad-MS (summer) } \\
\hline & $\begin{array}{r}\text { measured } \\
\text { exact } \\
\text { protonated } \\
\text { mass }\end{array}$ & $\begin{array}{r}\text { Sensitivity } \\
\left(\mathrm{ncps} \mathrm{ppbv}^{-1}\right)\end{array}$ & $\begin{array}{r}\text { Limit of } \\
\text { detection } \\
(\mathrm{ppbv})^{\mathrm{c}}\end{array}$ & $\begin{array}{r}\text { measured } \\
\text { nominal } \\
\text { protonated } \\
\text { mass }\end{array}$ & $\begin{array}{r}\text { Sensitivity } \\
(\text { ncps ppbv }\end{array}$ & $\begin{array}{l}\text { Limit of } \\
\text { detection } \\
(\mathrm{ppbv})^{\mathrm{d}}\end{array}$ \\
\hline Methanol & 33.033 & 12.8 & 0.011 & 33 & $17.9^{\mathrm{b}}$ & 0.415 \\
\hline Ethanol & 47.048 & 1.1 & 0.066 & - & - & - \\
\hline Ethanol/formic acid & - & - & - & 47 & $16.2^{\mathrm{b}}$ & 0.092 \\
\hline Acetone & 59.049 & 22.4 & 0.003 & 59 & $28.5^{\mathrm{b}}$ & 0.013 \\
\hline Acetaldehyde & 45.033 & $22.4^{\mathrm{a}}$ & 0.010 & 45 & $28.5^{\mathrm{b}}$ & 0.036 \\
\hline Acetic acid & 61.028 & $22.4^{\mathrm{a}}$ & 0.008 & 61 & $17.5^{\mathrm{b}}$ & 0.031 \\
\hline Isoprene & 69.069 & 10.6 & 0.002 & 69 & $12.7^{\mathrm{b}}$ & 0.021 \\
\hline MVK/MACR & 71.09 & $22.4^{\mathrm{a}}$ & $<0.001$ & 71 & $28.1^{\mathrm{b}}$ & 0.009 \\
\hline Monoterpenes & 81.070 and 137.132 & 15.0 & 0.004 & 81 and 137 & $18.5^{\mathrm{b}}$ & 0.029 \\
\hline Benzene & 79.054 & 12.5 & 0.001 & 79 & 16.9 & 0.008 \\
\hline Toluene & 93.069 & 14.8 & $<0.001$ & 93 & 16.9 & 0.015 \\
\hline C-8 aromatics & 107.085 & 16.2 & $<0.001$ & 107 & 15.9 & 0.010 \\
\hline Acetonitrile & 42.033 & 22.6 & 0.001 & 42 & $19.2^{\mathrm{b}}$ & 0.013 \\
\hline
\end{tabular}

\footnotetext{
${ }^{a}$ These sensitivities were not measured in calibrations, and acetone sensitivity was used instead. ${ }^{\mathrm{b}}$ These sensitivities were not measured in calibrations, but calculated using proton transfer reaction rate coefficients and transmission coefficients. ${ }^{\mathrm{c}}$ Calculated for a $30 \mathrm{~min}$ integration time. ${ }^{\mathrm{d}}$ Calculated for an integration time of $2 \mathrm{~s}$, except for mass $33(0.5 \mathrm{~s})$ and for masses $\geq 107(5 \mathrm{~s})$.
}

air through a heated inlet line ( $4 \mathrm{~m}$ long), made either of deactivated Sulfinert (winter) or teflon (summer) tube, installed at $3 \mathrm{~m}$ height in a forest gap. The inlet line was filtered with a teflon membrane (winter) or glass wool (summer) to prevent dust and particle intake. System background for both instruments was measured approximately every two hours by sampling zero air made by passing air through a catalytic converter, and instrument sensitivities were obtained by frequent calibrations with gas standards (Table 1).
For VOC monitoring during the winter measurements, a newly developed Proton Transfer Reaction-Time of FlightMass Spectrometer (PTR-ToF-MS) was deployed. It combined a Time-of-Flight MS detector (Tofwerk AG, Switzerland) with the characteristic chemical ionization system that defines PTR systems. A thorough description and characterization of the PTR-TOF instrument is given by Graus et al. (2010) and the data reduction method used is described by Müller et al. (2010). The PTR-ToF-MS drift tube was 
Table 2. Minimum and maximum VOC mixing ratios (ppbv) recorded at MSY station during the winter and summer campaigns.

\begin{tabular}{|c|c|c|c|c|c|c|c|c|}
\hline \multirow[b]{2}{*}{ VOC } & \multicolumn{4}{|c|}{ Winter } & \multicolumn{4}{|c|}{ Summer } \\
\hline & Minimum & Maximum & $\begin{array}{r}\text { Hourly } \\
\text { averages } \\
\text { minimum }\end{array}$ & $\begin{array}{r}\text { Hourly } \\
\text { averages } \\
\text { maximum }\end{array}$ & Minimum & Maximum & $\begin{array}{r}\text { Hourly } \\
\text { averages } \\
\text { minimum }\end{array}$ & $\begin{array}{r}\text { Hourly } \\
\text { averages } \\
\text { maximum }\end{array}$ \\
\hline Methanol & 0.256 & 9.761 & 1.279 & 2.704 & 1.410 & 13.400 & 4.142 & 6.053 \\
\hline Ethanol/formic acid & $<0.066$ & 8.950 & 0.474 & 2.083 & 0.374 & 4.480 & 1.146 & 2.869 \\
\hline Acetone & 0.257 & 3.897 & 0.787 & 1.547 & 0.967 & 5.950 & 2.260 & 3.834 \\
\hline Acetaldehyde & 0.071 & 1.885 & 0.227 & 0.657 & $<0.036$ & 3.370 & 0.541 & 1.264 \\
\hline Acetic acid & 0.026 & 5.348 & 0.393 & 1.428 & 0.270 & 5.640 & 1.317 & 2.940 \\
\hline Isoprene & 0.003 & 0.184 & 0.019 & 0.071 & $<0.021$ & 1.250 & 0.152 & 0.753 \\
\hline MVK/MACR & 0.002 & 0.153 & 0.011 & 0.047 & $<0.009$ & 1.040 & 0.166 & 0.537 \\
\hline Monoterpenes & $<0.004$ & 0.234 & 0.005 & 0.067 & 0.035 & 2.560 & 0.127 & 1.421 \\
\hline Benzene & 0.059 & 0.470 & 0.105 & 0.190 & 0.008 & 0.194 & 0.039 & 0.090 \\
\hline Toluene & 0.001 & 1.903 & 0.057 & 0.408 & $<0.015$ & 1.340 & 0.083 & 0.467 \\
\hline C8-aromatics & 0.003 & 1.328 & 0.031 & 0.249 & $<0.010$ & 0.821 & 0.091 & 0.272 \\
\hline Acetonitrile & 0.027 & 0.258 & 0.075 & 0.101 & 0.037 & 0.588 & 0.159 & 0.216 \\
\hline
\end{tabular}

operated at $2.3 \mathrm{mbar}, 600 \mathrm{~V}$, and $50^{\circ} \mathrm{C}$ which corresponds to an $\mathrm{E} / \mathrm{N}$ ratio of $130 \mathrm{Td}$ ( $\mathrm{E}$ being the electric field strength and $\mathrm{N}$ the gas number density; $1 \mathrm{Td}=10^{-17} \mathrm{~V} \mathrm{~cm}^{2}$ ). Sensitivity calibrations for the PTR-TOF were performed by dynamic dilution of VOCs using a multi-component gas standard (Apel Riemer Environmental Inc., USA). The calibration gas contained acetone, acetonitrile, acrolein, benzene, 2-butanone, ethanol, formaldehyde, hexanone, isoprene, methanol, monoterpenes ( $\alpha$-pinene), toluene, o- and p-xylene. The time-of-flight path length is sensitive to temperature variation and therefore mass scale calibration was done continuously by adding dichlorobenzene (protonated $\mathrm{m} / z=146.9763$ ) and trichlorobenzene (protonated $\mathrm{m} / z=180.9373$ ) to the PTR-TOF inlet.

During the summer measurements, the site was equipped with a High Sensitivity Proton Transfer ReactionQuadrupole-Mass Spectrometer (PTR-Quad-MS, described by Lindinger et al., 1998). This instrument was operated at $2.3 \mathrm{mbar}, 580 \mathrm{~V}$, and $50^{\circ} \mathrm{C}$ drift tube conditions, which corresponds to a E/N of $122 \mathrm{Td}$. Sensitivity calibrations for the PTR-Quad-MS were performed by dynamic dilution of an aromatic VOC gas standard (TO-14A, Restek, Bellefonte, PA, USA). The calibration gas contained benzene, toluene, chlorobenzene, dichlorobenzene, styrene, ethyl benzene, xylene, trimethylbenzene, and trichlorobenzene. In addition, vapors of isoprene and monoterpene ( $\alpha$-pinene and limonene) liquid standards were sampled to measure their relative transmission efficiency and their fragmentation pattern. Mixing ratios of VOCs not present in the calibration standard were calculated taking into account the VOC relative transmission, their measured fragmentation pattern and their proton transfer reaction rate coefficients reported elsewhere (Zhao and Zhang, 2004) as described by de Gouw and Warneke (2007).
These PTR systems have differences in the mass resolution of the VOCs analyzed, since the ToF MS is capable of separating isobaric compounds that the PTR-Quad-MS detects at one single mass. Such differences are shown in Table 1, where the masses measured and the VOC assigned to each mass are displayed. In the case of the ToF, isobaric VOCs can be distinguished according to their exact mass, while in the case of the Quadrupole the identification of VOCs is liable to interferences, although identification was based on calibrations, experience, and well-known and almost interference-free VOC-mass correspondences (de Gouw and Warneke, 2007). For example, we report measurements of protonated mass 47 in summer and attribute them to formic acid/ethanol (Table 1), because the PTR-QuadMS is not able to separate these two compounds. In the winter measurements, the PTR-ToF-MS could have identified each of them separately, but only ethanol was detected (Table 1). In the case of monoterpenes, neither PTR-MS system could separate the different isomeres. Thus, additionally, samples were taken for monoterpene determination via gas chromatography-mass spectrometry (GC-MS). Using a teflon line to sample from the same inlet point as the PTR-MS systems and by means of a pump (model Qmax, manufactured by Supelco, USA), ambient air was drawn (at $500 \mathrm{ml} \mathrm{min}^{-1}$ for $20 \mathrm{~min}$, without ozone scrubber) through a tube $(8 \mathrm{~cm}$ long and $0.3 \mathrm{~cm}$ internal diameter) manually filled with terpene adsorbents Carbopack B, Carboxen 1003, and Carbopack Y (Supelco, Bellefonte, PA, USA) separated by plugs of quartz wool. The cartridges were prepared and then analysed in the laboratory as described in Llusià et al. (2010). This sampling was conducted once per hour from $06: 00 \mathrm{~h}$ to 21:00 h GMT on selected days to obtain a daytime hourly profile of monoterpene speciation. 
For clarity, we have divided the measured VOCs into three groups according to their structure and characteristics. One group is composed of short-chain oxygenated compounds (oxVOCs): methanol, acetone, acetaldehyde, acetic acid, and formic acid/ethanol (see Seco et al., 2007 for a review). The second group is formed by the isoprenoids: isoprene and monoterpenes, and we additionally included here the compounds methyl vinyl ketone (MVK) and methacrolein (MACR), which are oxidation products of isoprene. The third group contains the aromatic volatiles: benzene, toluene, and C8-aromatics (a term that includes compounds like xylenes). Finally, we also analyzed acetonitrile.

\subsection{Meteorology and measurements of inorganic gaseous pollutants}

During both periods, meteorological data such as temperature, relative humidity, wind direction and speed, precipitation, and solar radiation was gathered from an air monitoring station that is part of the EUSAAR network (European Supersites for Atmospheric Aerosol Research, recently created to integrate the measurements of atmospheric aerosol properties at 21 high quality European ground-based stations). This station was located $200 \mathrm{~m}$ away from the PTR-MS sampling site, in the same slope of the mountain and at the same altitude (720 ma.s.1.). The actual measurements were taken from a tower, at $10 \mathrm{~m}$ height (Pandolfi et al., 2011). In summer there were calibration factor problems for the wind speed data, so we recalibrated the measurements according to previous research conducted at the same area and according to the data gathered in three nearby meteorological stations (Santa Maria de Palautordera, Viladrau, and Tagamanent at 13,8 , and $7 \mathrm{~km}$ of distance).

Real time measurements of ambient air levels of $\mathrm{O}_{3}$ and $\mathrm{NO}_{\mathrm{x}}$ ( $\mathrm{NO}$ and $\mathrm{NO}_{2}$ ) were provided by conventional gas phase air pollution monitors installed at the same station and maintained by the Department of the Environment of the Catalan Government (Generalitat de Catalunya). Levels of $\mathrm{NO}_{\mathrm{x}}$ were measured by a chemiluminescence analyzer (model 42iTL, Thermo Scientific) and those of $\mathrm{O}_{3}$ by the ultraviolet photometric method (model 48AUV, MCV S.A., Barcelona).

\subsection{Data analysis and statistics}

Calculations of VOC mixing ratios from the PTR-MS data, together with the treatment and graphing of the data time series, were conducted using Igor Pro (Wavemetrics Inc., Portland, OR, USA). The correlation coefficients between all the available data variables (VOC mixing ratios, wind, temperature, solar radiation, and $\mathrm{NO}_{2}$ and $\mathrm{O}_{3}$ ) were calculated, in order to conduct a preliminary screening of possible relationships (see Supplement). For this purpose the Statistica (StatSoft Inc., Tulsa, USA) package was used. In addition, wavelet analysis was applied to analyze the relationship between VOC mixing ratios and ozone concentrations in summer (see Supplement).

\section{Results}

\subsection{Meteorological conditions and atmospheric dynamics}

The MSY site presents a typical Mediterranean climate with warm summers, temperate winters and irregular precipitation rates (Pérez et al., 2008). In fact, precipitation was practically nonexistent during the periods reported in this paper. Average maximum solar radiation reached around $600 \mathrm{~W} \mathrm{~m}^{-2}$ in winter and $800 \mathrm{~W} \mathrm{~m}^{-2}$ in summer (Fig. 2), and consequently the average temperatures differed $11-15^{\circ} \mathrm{C}$ between the two periods $\left(7-13^{\circ} \mathrm{C}\right.$ and $19-27^{\circ} \mathrm{C}$ daily averages in winter and summer, respectively), while relative humidity showed almost identical daily profiles (Fig. 2).

Air circulation in the MSY site is strongly determined by the topography of the valley, and two main wind directions are usually recorded (Fig. 3). The southerly direction is present when the mountain and sea breezes develop during daytime, entering the valley from the south. This is when the highest wind speeds are usually recorded. The westerly direction corresponds to intense advections from the north and north-west, channeled into the valley with a western direction (as was the case during the period 5-7 March), and to drainage flows during the night (Pérez et al., 2008).

The highest wind speeds for winter were measured during the Atlantic advection scenario (days 5-7 March), with values of up to $10 \mathrm{~m} \mathrm{~s}^{-1}$. This scenario is a typical atmospheric phenomenon of this region, characterized by Atlantic advection conditions with strong northwestern winds that promote a cleaning of the atmosphere by renewing the polluted atmosphere with fresh air masses in the entire region. More information regarding the meteorological scenarios and synoptic conditions of the MSY area during this study can be found in the articles by Jorba et al. (2011) and Pandolfi et al. (2011).

\section{2 $\mathrm{O}_{3}, \mathrm{NO}$ and $\mathrm{NO}_{2}$ concentrations}

Ozone concentrations showed similar values during the night and early morning both in winter and summer (average around $75 \mu \mathrm{g} \mathrm{m}^{-3}, 37.5 \mathrm{ppbv}$ ). About two hours after sunrise they increased up to an average of $128 \mu \mathrm{g} \mathrm{m}^{-3}$ (64 ppbv) in summer (around 14:00 h GMT) and $95 \mu \mathrm{g} \mathrm{m}^{-3}$ (47.5 ppbv) in winter (peaks around 11:00 h and 15:00 h GMT)(Fig. 4). $\mathrm{NO}_{2}$ concentrations showed a similar daily profile, with very similar summer and winter values during night and morning (average around $2 \mu \mathrm{g} \mathrm{m}^{-3}, 1 \mathrm{ppbv}$ ), and then an increase (delayed by around $2 \mathrm{~h}$ with respect to the rise in $\mathrm{O}_{3}$ ) reaching a first peak at 13:00 h and a second peak around 17:00 h (winter) or 19:00 h (summer). Maximum average values were $11.6 \mu \mathrm{g} \mathrm{m}^{-3}$ (6 ppbv) for winter and $7.5 \mu \mathrm{g} \mathrm{m}^{-3}$ (3.9 ppbv) for summer (Fig. 4). NO concentrations were usually below the limit of detection $\left(<1 \mu \mathrm{g} \mathrm{m}^{-3}, 0.8 \mathrm{ppbv}\right)$ of the instrumentation deployed by the government at MSY. Only some episodes reaching peaks of $2-6 \mu \mathrm{g} \mathrm{m}^{-3}$ (1.6-4.8 ppbv) 

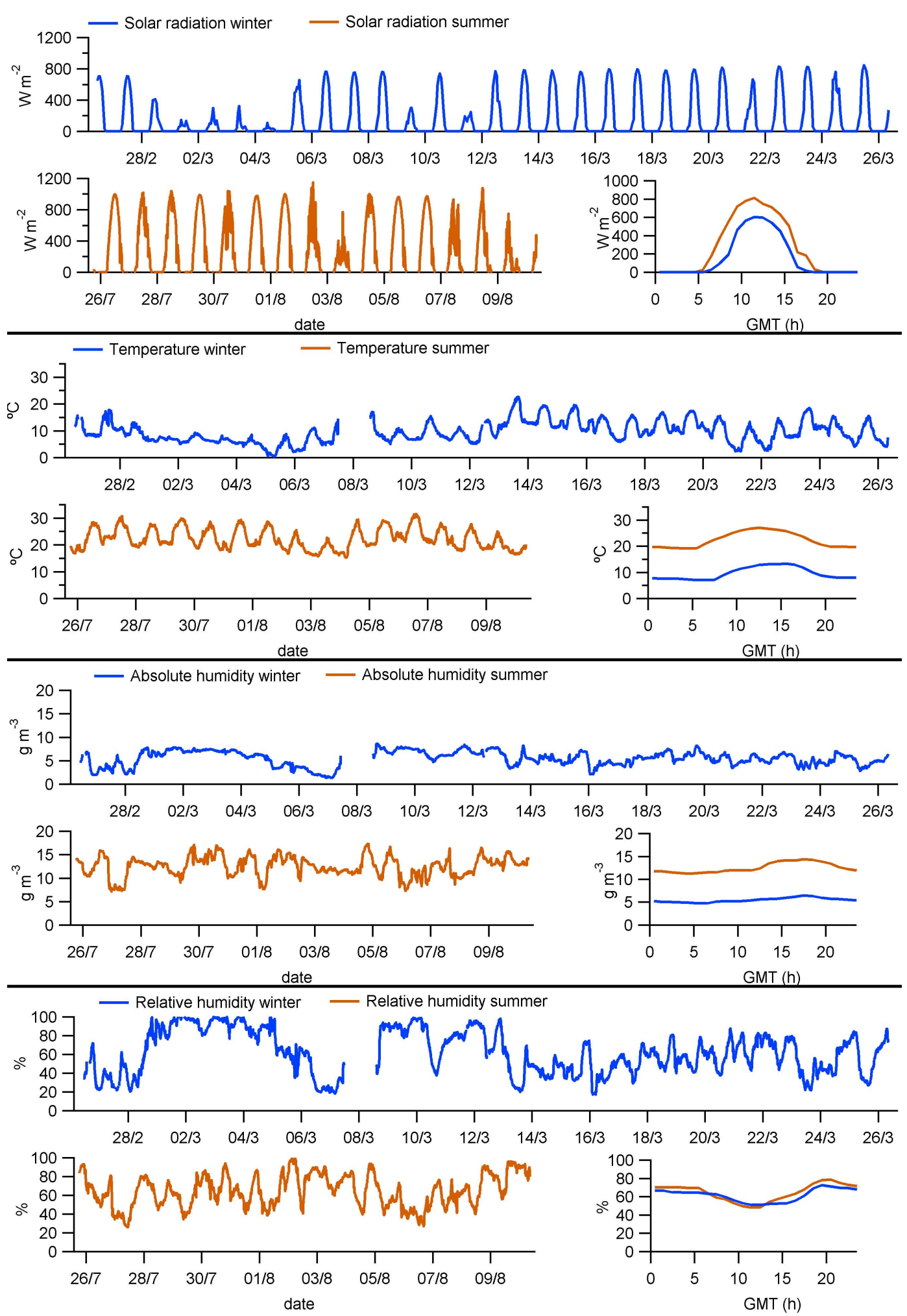

Fig. 2. Solar radiation, temperature, and absolute and relative humidity during the winter period (upper graph of each panel), during the summer period (lower left graph) and their mean daily cycles (hourly averages) for both periods (lower right graph). Date labels indicate 00:00 GMT. 

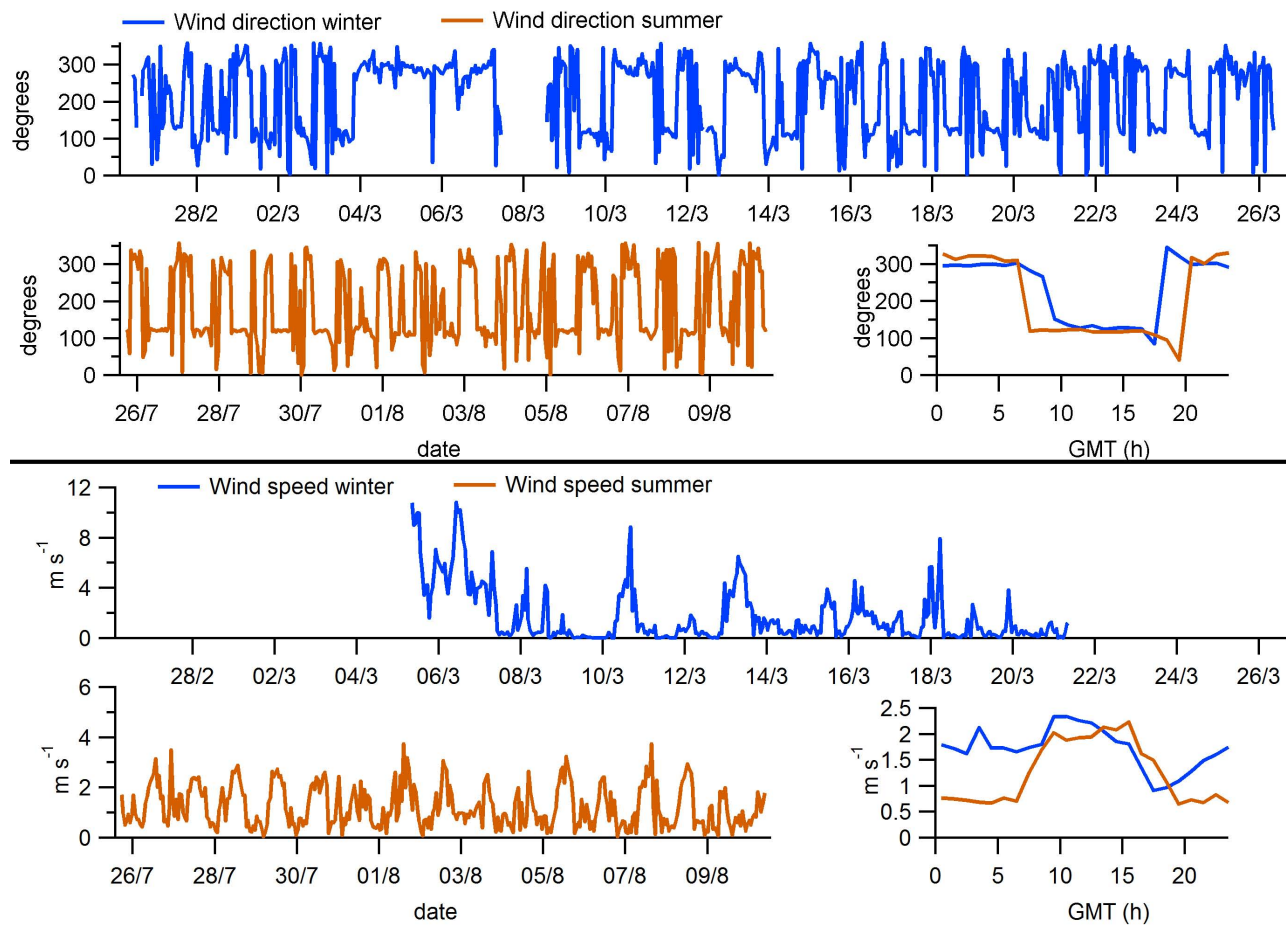

Fig. 3. Wind direction and speed during the winter period (upper graph of each panel), during the summer period (lower left graph) and their mean daily cycles (hourly averages) for both periods (lower right graph). Note the different scaling for graphs on wind speed seasonal trend graphs. Date labels indicate 00:00 GMT.

in winter were recorded, resulting in maximum winter averages of $1.6 \mu \mathrm{g} \mathrm{m}^{-3}$ (1.3 ppbv), which took place when $\mathrm{NO}_{2}$ concentrations also peaked (data not shown).

\subsection{VOC mixing ratios}

\subsubsection{Seasonal differences}

All the VOC mixing ratios measured during the winter and summer campaigns as well as their mean daily cycles are displayed in Figs. 5, 6, and 7, while Table 2 lists maximum and minimum values of the same data. Almost all the VOCs analyzed showed higher average mixing ratios during the summer period than in winter. Only some aromatic VOCs, normally linked to anthropogenic sources, had lower (benzene) or similar (toluene and C8-aromatics) mixing ratios in summer compared to winter (Fig. 7). The greatest difference in mixing ratios between seasons corresponded to the isoprenoids (Fig. 6), as seen by the 10 -fold (isoprene and also its degradation products MVK/MACR) and 21-fold (monoterpenes) increases in their hourly average maxima (Table 2). In the case of monoterpenes, GC-MS analysis showed that the most abundant species were the same in winter and summer, $\alpha$-pinene being the most abundant one among them (51.4/31.9\% in winter/summer), followed by sabinene $+\beta$ pinene $(27.1 / 28.8 \%)$ and limonene (9.5\% in both seasons).
The VOC species with the highest mixing ratios in both winter and summer was methanol (showing peaks of up to 9.7/13.4 ppbv and maximum hourly averages of $2.7 / 6 \mathrm{ppbv}$ in winter/summer), followed in winter by ethanol (with peaks of $8.9 \mathrm{ppbv}$ and maximum averages of $2 \mathrm{ppbv}$ ) and in summer by acetone (reaching up to $5.9 \mathrm{ppbv}$ and maximum averages of $3.8 \mathrm{ppbv}$, Fig. 5, Table 2). Regarding isoprenoids, monoterpenes were more abundant (reaching maximum averages of $1.4 \mathrm{ppbv}$ ) than isoprene (reaching maximum averages of $0.75 \mathrm{ppbv}$ ) in summer, whereas in winter both VOCs showed similar mixing ratios (around 0.07 ppbv maximum averages). Among the aromatic VOCs, toluene presented the highest mixing ratios (with peaks below $2 \mathrm{ppbv}$ and maximum averages around $0.4 \mathrm{ppbv}$ ) in both seasons (Fig. 7).

\subsubsection{Average daily cycles}

Looking at the daily average mixing ratios and in general terms, all VOCs presented very similar diel cycles with maximum values during the daytime (Fig. 8). Linear correlations between all of them showed variable Pearson's correlation coefficients $(r)$, but they were always significant $(p<0.01)$ above 0.31 and with an average of 0.73 in winter and 0.68 in summer (see Table S1 in Supplement).

When considering the different groups of VOCs separately, it is apparent that although their daily pattern is not 

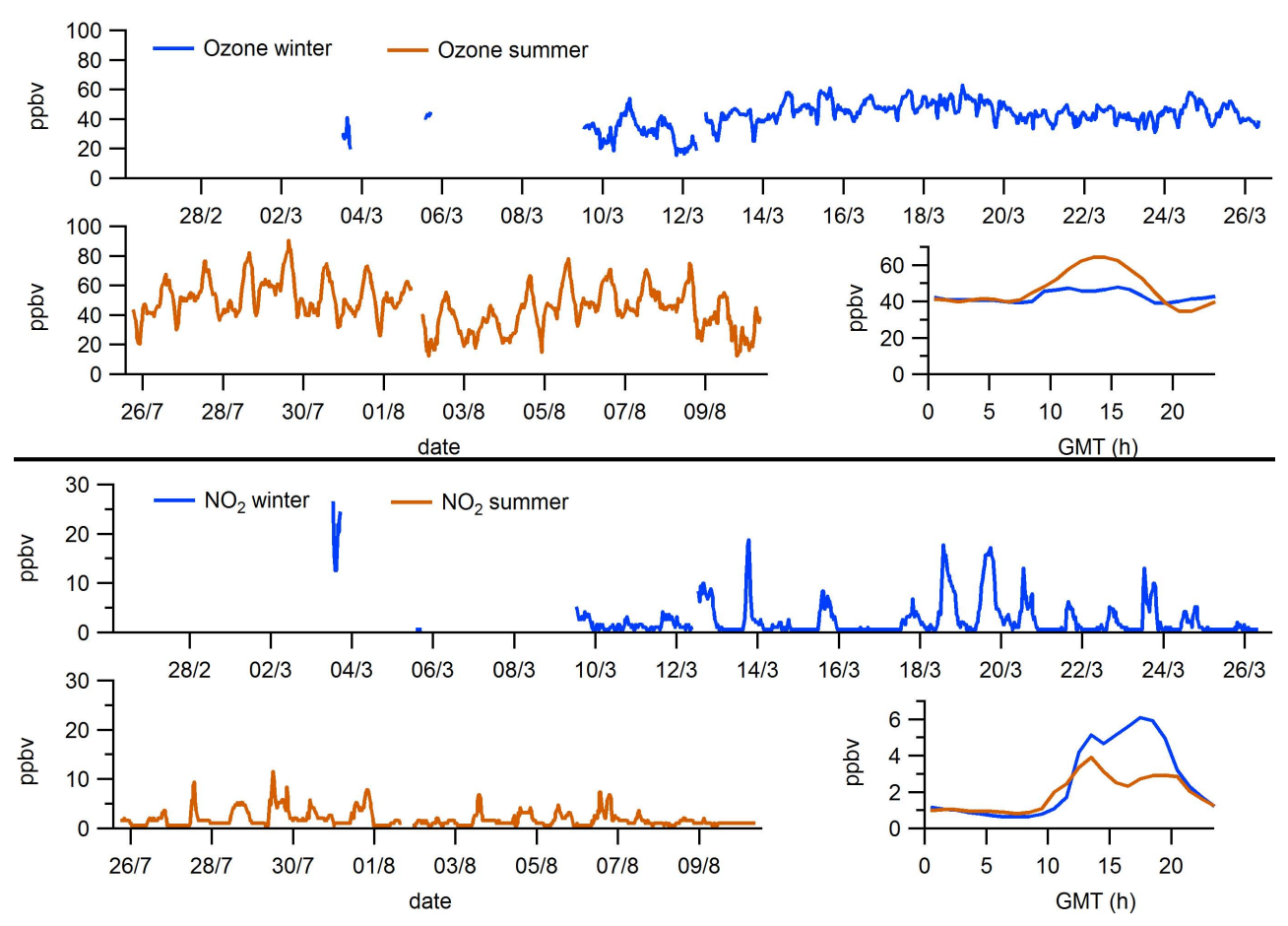

Fig. 4. Ozone and nitrogen dioxide mixing ratios during the winter period (upper graph of each panel), during the summer period (lower left graph) and their mean daily cycles (hourly averages) for both periods (lower right graph). Date labels indicate 00:00 GMT.

exactly the same in summer as in winter all short-chain oxygenated VOCs (oxVOCs) and aromatics have almost the same daily pattern. Relationships between isoprenoid VOCs (isoprene and monoterpenes) showed a mixed behaviour, depending on the season. In winter isoprene showed a diel cycle resembling that of aromatic or oxVOCs (Fig. 8), while in summer its mean daily cycle was not exactly like the any other cycle, neither that of oxVOCs, aromatics nor monoterpenes (Fig. 8).

\section{Discussion}

Our results show almost no seasonal variability for aromatic VOCs, whereas short-chain oxygenated VOCs and isoprenoids in particular presented much higher mixing ratios (one order of magnitude greater) in summer when the vegetation emission rates increased considerably (also by one order of magnitude, Llusià et al., in preparation). The highest diurnal concentrations of ozone increased in summer too, probably due to more intense photochemical activity and the higher VOC mixing ratios.

The daily variations in the mixing ratios of most VOCs measured in this study show a very similar pattern. This fact, along with its correspondence in time with the wind direction and speed (Fig. 8), suggests that the changes in VOC mixing ratios are driven by the wind regime of the MSY site, which advects air masses from the surrounding semi-urban and urban areas including the metropolitan area of Barcelona during the daytime, and from the north-western pastures and forests during the night.

\subsection{Seasonal VOC mixing ratios}

\subsubsection{OxVOCs}

Methanol is the second most abundant organic gas in the atmosphere after methane (Jacob et al., 2005), with mixing ratios lying globally within the range $0.2-195 \mathrm{ppbv}$ (Seco et al., 2007). At MSY methanol reached the highest mixing ratios among the VOCs measured in both seasons (Fig. 8; Table 2), with peaks up to $9.7 \mathrm{ppbv}$ in winter and $13.4 \mathrm{ppbv}$ in summer. Its direct sources, as well as those of the other short-chain oxygenated VOCs, include emissions from the vegetation (Filella et al., 2009), soil, dead plant matter, as well as anthropic sources such as biomass and fossil fuel combustion and industrial processes. In addition, oxVOCs can be formed secondarily as products of reactions of other biogenic or anthropogenic - hydrocarbons of higher molecular weight. This is in fact the major atmospheric source of some of these oxVOCs, such as acetaldehyde (Seco et al., 2007). So, the difference in oxVOC mixing ratios between seasons may be attributed mainly to two phenomena: (i) the larger biogenic emissions in summer due to the increased physiological activity of vegetation, and (ii) increased secondary production in summer due to greater photochemical 

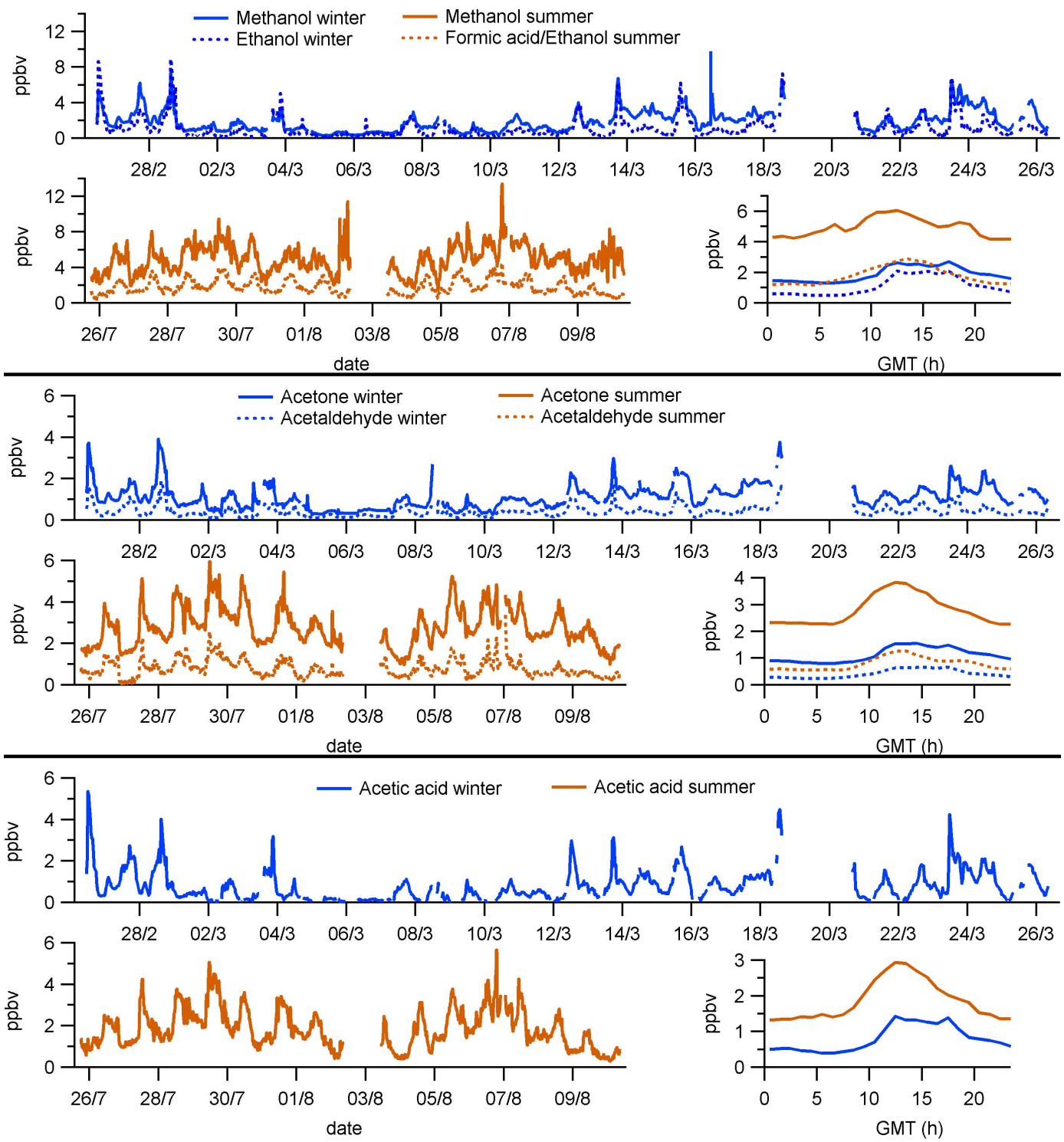

Fig. 5. Short-chain oxygenated VOCs measured at MSY, showing their mixing ratios during the winter period (upper graph of each panel), their mixing ratios during the summer period (lower left graph) and their mean daily cycles (hourly averages) for both periods (lower right graph). Date labels indicate 00:00 GMT.

reactivity as a result of the higher temperatures and insolation. These compounds are characterized by a variety of atmospheric lifetimes, which span from over 10 days for acetone and methanol (Jacob et al., 2005; Singh et al., 2004) to a few hours for acetaldehyde (Possanzini et al., 2002). This may be the reason why acetone and methanol had the highest mixing ratios in this group, even at night, and also why acetaldehyde showed the lowest mixing ratios of all the oxVOCs measured (Fig. 8).

\subsubsection{Isoprenoids}

It is generally considered that the main atmospheric source of isoprenoid VOCs is direct emission from vegetation (Guenther et al., 1995). As in the case of oxVOCs, increased emission rates of plants concurring with higher temperatures and radiation must be the reason for the great rise in their mixing ratios in summer compared to winter, which was the highest rise monitored in MSY (a 10- to 21-fold increase; Figs. 6 and 8; Table 2). Likewise, isoprenoid leaf-level emissions by $Q$. ilex measured during the campaign showed a similar increase of approximately one order of magnitude (Llusià et al., 2011). However, other factors such as dilution by mixing 

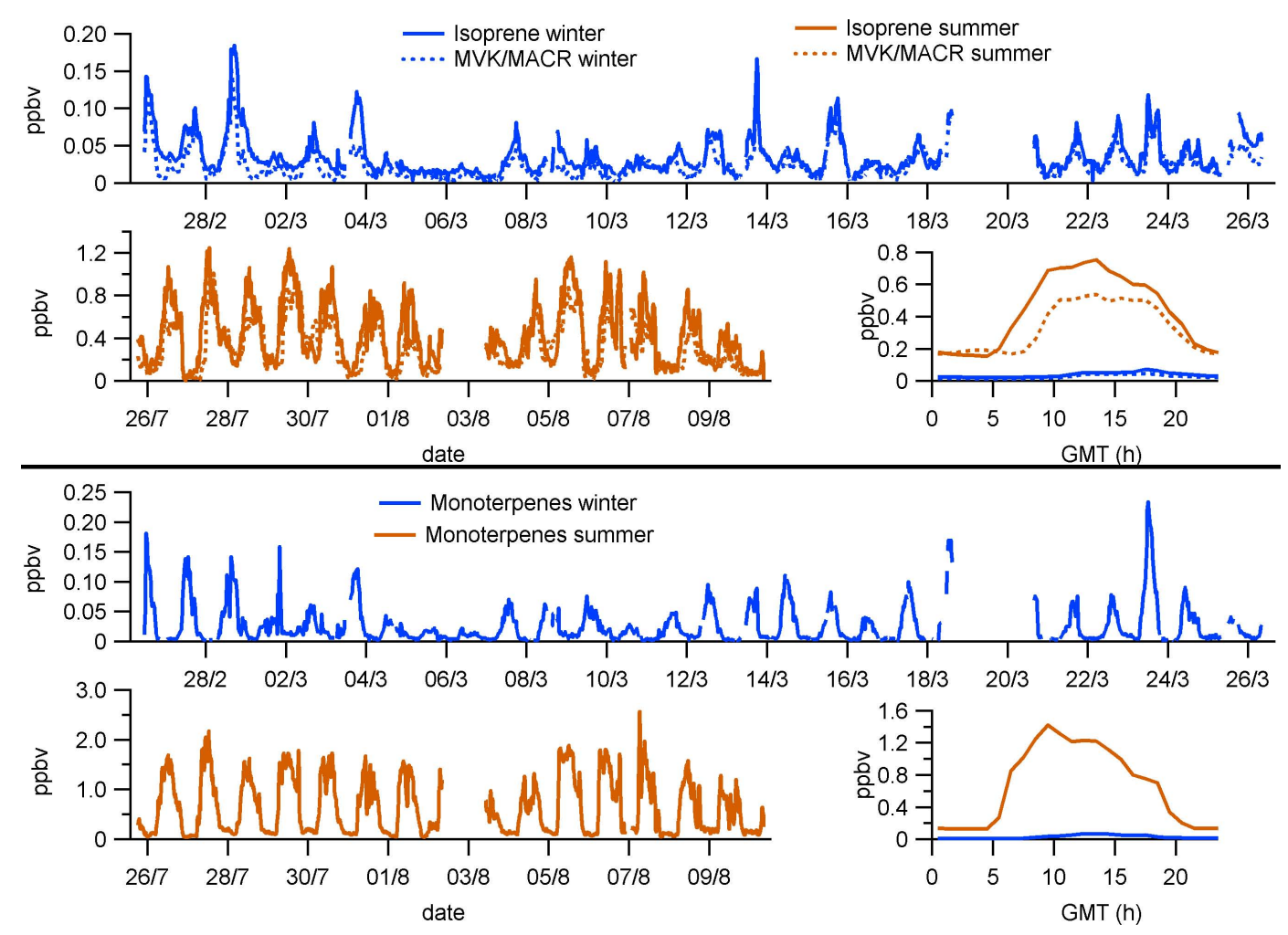

Fig. 6. Isoprenoid VOCs and MVK/MACR measured at MSY, showing their mixing ratios during the winter period (upper graph of each panel), their mixing ratios during the summer period (lower left graph) and their mean daily cycles (hourly averages) for both periods (lower right graph). Note the different scaling for the seasonal trend graphs. Date labels indicate 00:00 GMT.

and transport and changes in boundary layer play a role too in determining the isoprenoid mixing ratios measured at MSY.

\subsubsection{Aromatic VOCs}

Aromatic VOCs did not change substantially in mixing ratios between winter and summer at MSY (Figs. 7 and 8; Table 2), suggesting their emission sources are of similar strength all year round. Also, there are few sources of these compounds - mainly tailpipe exhaust - in the local environment of the MSY site, probably restricted to a little road in the valley and some small villages. Therefore their mixing ratios in MSY are assumed to come from relatively distant sources outside the valley. The aromatic VOC with the largest seasonal variation was benzene (winter levels doubled those of summer, see Table 2) but at the same time it was the aromatic VOC with lowest daily fluctuation (Fig. 7). The latter may be related to the fact that benzene has the longest atmospheric lifetime (in the order of days) among the aromatics measured (Atkinson, 2000) and for this reason it may be better mixed within the atmosphere.

\subsubsection{Acetonitrile}

Acetonitrile is considered a biomass burning marker (Holzinger et al., 1999), given that its main global source
(94\%) is biomass burning, with only a minor part (less than $6 \%$ ) arising from fossil fuel combustion (Holzinger et al., 2001a). In contrast with benzene, at MSY acetonitrile mixing ratio was double in summer compared to winter (Table 2). This was unexpected because in winter biomass burning used for domestic heating is more common than in summer in the area around MSY, and furthermore in summer the controlled burning of agricultural waste is limited by law. On the other hand, during summer, forest fires in the Mediterranean area are common and long range transport of acetonitrile could occur due to its relatively long atmospheric lifetime (Sanhueza et al., 2004), so the higher mixing ratios in summer suggest more extensive burning events in the Mediterranean area. Similarly to benzene, this relatively long atmospheric lifetime may yield good acetonitrile mixing in the atmosphere, and as a consequence the small daily variations of the mixing ratios (Fig. 8).

\subsection{Daily cycles and wind regime}

Mixing ratios of all VOCs at this forested site showed a marked diel cycle in both seasons, and a very similar pattern, in most cases, within one particular season. This is particularly apparent in winter, when on average all VOC levels except monoterpenes - and to a lesser extent, acetonitrile 

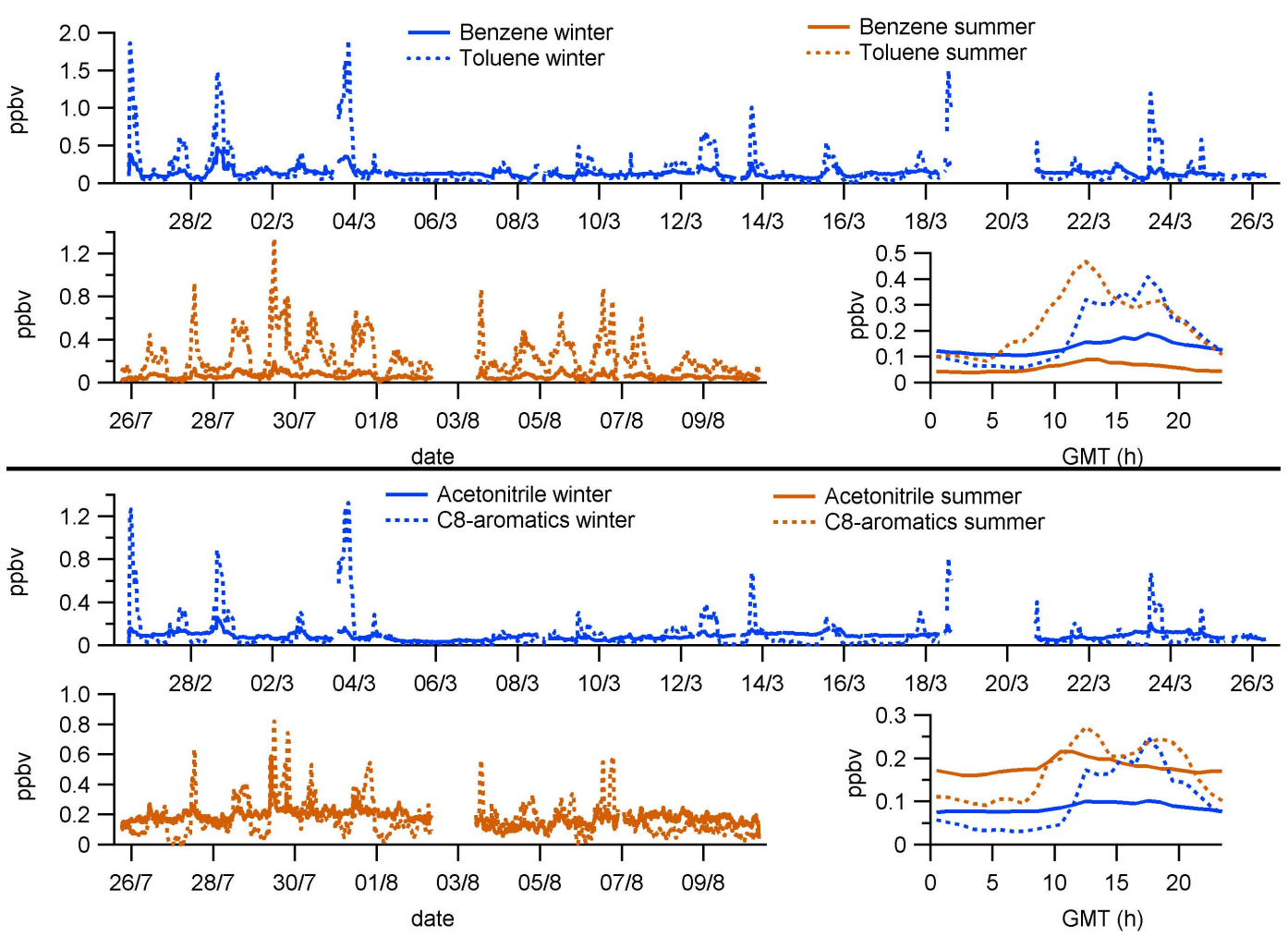

Fig. 7. Aromatic VOCs and acetonitrile measured at MSY, showing their mixing ratios during the winter period (upper graph of each panel), their mixing ratios during the summer period (lower left graph) and their mean daily cycles (hourly averages) for both periods (lower right graph). Note the different scaling for the seasonal trend graphs. Date labels indicate 00:00 GMT.

- rose at the same time in morning, had almost simultaneous peaks and decayed at the same moment in the evening (Fig. 8). Even the aromatic compounds followed this behaviour, despite having few local sources in the MSY valley. This common pattern indicates that the VOC mixing ratios measured at the site are mainly governed by the wind regime of the mountain. In winter, after sunrise the sea breeze starts to blow mountain upwards and VOC mixing ratios slightly increase, and about $2 \mathrm{~h}$ after that, they undergo a sharp increase. VOC levels are then maintained more or less constant until the wind changes direction and reduces speed, when at around 17:00 h GMT the sea breeze stops and the mountain drainage flow towards the valley starts instead. This general daily cycle of VOC mixing ratios driven by the wind is also observed in summertime. Such behaviour of atmospheric pollutants at MSY has been described by Pérez et al. (2008) and also for the same period of our study when comparing PM levels in the city of Barcelona and MSY (Minguillón et al., 2011; Pandolfi et al., 2011) . In this case, the levels of fine particulate matter $\left(\mathrm{PM}_{1}\right)$ increased in MSY when corresponding levels in Barcelona decreased. This was partly attributed to the mountain and sea breeze transport toward the MSY site.

Both biogenic and anthropogenic emissions of gaseous and particulate matter accumulate in the valleys and depressions (including the Barcelona metropolitan area) during the night and early morning. Later in the morning the air masses from the Barcelona metropolitan area are advected to MSY by the sea and mountain breezes, passing over further heavily industrialized areas, with some cities in the range of 50000-100 000 inhabitants and a number of highways, and hence taking up more pollutants. Assuming a $2 \mathrm{~m} \mathrm{~s}^{-1}$ average daytime wind speed for both seasons, these air masses can travel around $7 \mathrm{~km}$ per hour. At the same time, photochemical reactions take place within the air mass (e.g. ozone production, VOC degradation, etc.), so the pollution plume is aged when it reaches MSY.

While the ozone concentration at MSY is the result of photochemical production that has occurred over several hours (Sillman, 1999), in addition this air mass which is transported inland, loaded with a variety of anthropogenic pollutants (including VOCs), mixes at the forested site with new biogenic VOCs. This mixing process with VOCs produced locally at the valley where MSY is located may enhance ozone production (Calfapietra et al., 2009; Hewitt et al., 2011; Peñuelas and Staudt, 2010). Ozone production depends on the $\mathrm{VOC} / \mathrm{NO}_{\mathrm{x}}$ ratio of the air, and the MSY valley atmosphere in the early morning, especially in summer, has $\mathrm{NO}_{\mathrm{x}}$-sensitive conditions $\left(\mathrm{VOC} / \mathrm{NO}_{\mathrm{x}}>15\right)$ due to the high local biogenic emissions and the low concentrations 

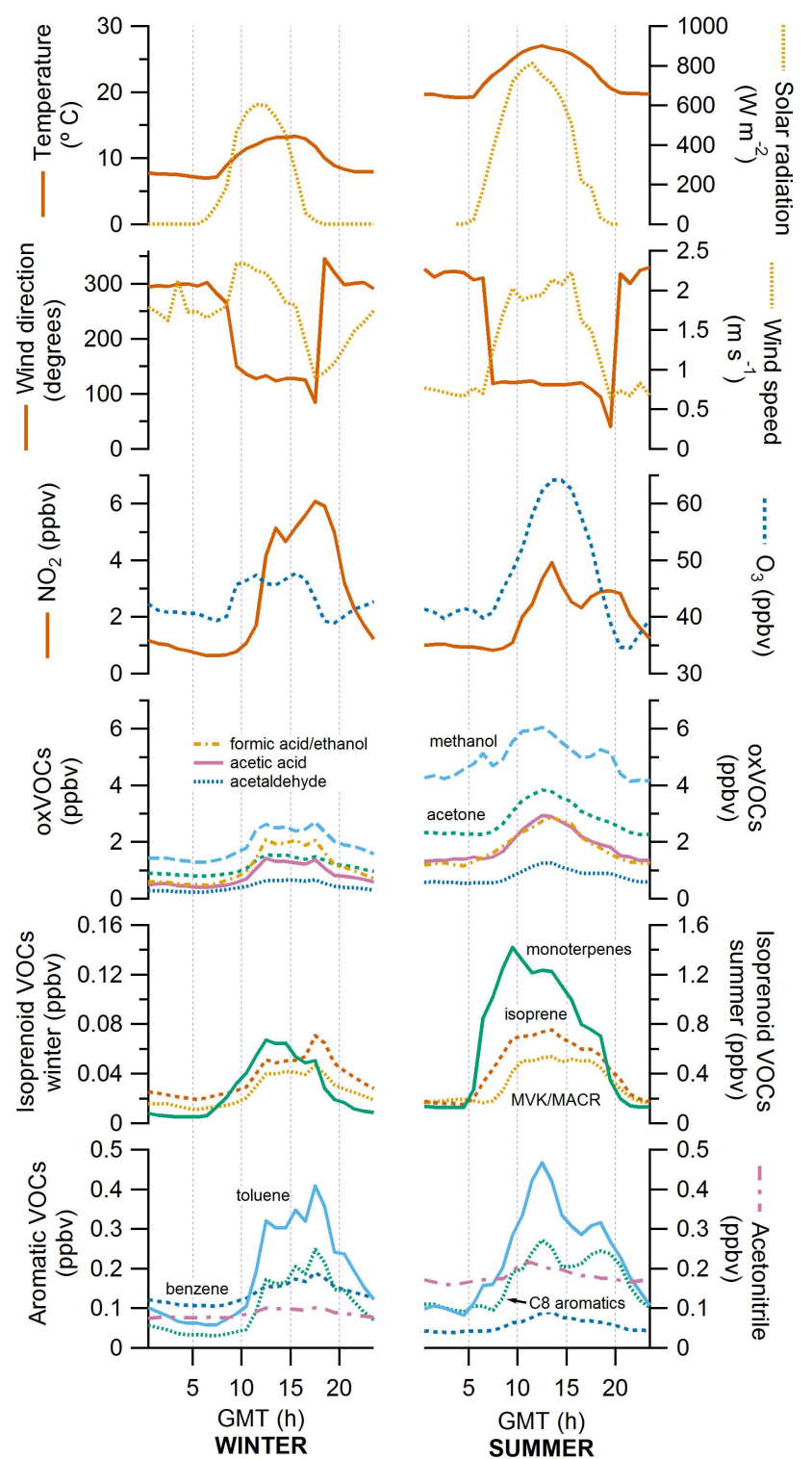

Fig. 8. Mean daily cycles of the majority of the variables studied, comparing winter (left) with summer (right). VOC mixing ratios are split into three separate panels, corresponding to Figs. 5, 6, and 7: (i) one for short-chain oxVOCs: methanol, acetone, formic acid/ethanol, acetic acid and acetaldehyde; (ii) the second one for isoprenoid VOCs: monoterpenes, and isoprene and its degradation products MVK/MACR; (iii) the last panel for acetonitrile and aromatic VOCs: benzene, toluene, and C8-aromatics. Note the different scaling for the isoprenoid VOCs between winter and summer (one order of magnitude higher in summer).

of $\mathrm{NO}_{\mathrm{x}}$, that may change to more favorable conditions for ozone production when the breeze advects $\mathrm{NO}_{\mathrm{x}}$ from the metropolitan area (see Supplement). This could partially explain the higher ozone concentration found in MSY (means of $75 \mu \mathrm{g} \mathrm{m}^{-3}$ at night and $90-125 \mu \mathrm{g} \mathrm{m}^{-3}$ by day) compared to Barcelona city in both seasons (means of $40-50 \mu \mathrm{g} \mathrm{m}^{-3}$ at night and 60-70 $\mu \mathrm{g} \mathrm{m}^{-3}$ at day; Pandolfi et al., 2011). In addition, another important cause of these higher ozone levels in the mountains is the lack of fresh $\mathrm{NO}$ emissions. In urban and semi urban environments the consumption of $\mathrm{O}_{3}$ by freshly emitted $\mathrm{NO}$ to form $\mathrm{NO}_{2}$ represents an important sink for ozone. In the case of MSY, the air mass being advected has low NO mixing ratios because it has been consumed by photochemical reactions before arriving to the mountain. In addition, summer higher solar radiation and temperature promote photochemical reactions, further explaining the higher daytime ozone concentrations registered in summer.

Monoterpenes are a special case as regards this airborne VOC transport from polluted areas. In winter and summer, monoterpene mixing ratios started to rise earlier than the other VOCs, as soon as solar radiation started to increase too (Fig. 8), and this was probably due to the local origin of monoterpenes. Monoterpenes have an atmospheric lifetime on the range of an hour (Atkinson, 2000) so the origin of those detected at MSY must be no further than $7 \mathrm{~km}$ from the station. Monoterpenes were emitted by holm oaks which densely populate the MSY site and the valley just beneath. Holm oaks are known monoterpene emitters (Llusià and Peñuelas, 2000; Peñuelas and Llusià, 1999a), as confirmed by leaf-level measurements performed at MSY during this campaign (Llusià et al., 2011). The case of isoprene was, however, different. Although it is normally considered a biogenic VOC, it has also known anthropic sources, like automobile exhaust (Borbon et al., 2001), while in the case of monoterpenes anthropic origins are scarce. The difference in the mean wintertime diel cycle between isoprene and monoterpenes reflected in Fig. 8 may be indicative that most of the isoprene detected in winter was also advected to MSY and maybe a considerable amount was anthropogenic. A previous study in an semi-urban area in the metropolitan region of Barcelona (upwind of MSY) described this dominance of the human-related sources of isoprene in winter (Filella and Peñuelas, 2006). In addition, winter monoterpene emissions by the valley oaks were low (Llusià et al., 2011), as reflected in the low mixing ratios reported. Thus isoprene emission must have been even lower because the emission of isoprene has been reported to be less than $5 \%$ of the emission of monoterpenes for this evergreen tree species (Peñuelas et al., 2009). Of course we can not rule out the possibility that different plant species of the vegetation found in the trajectory of the air masses as they were advected by the sea breeze (i.e. before entering the MSY valley) were responsible for loading those air masses with isoprene. With an atmospheric lifetime of around $1.5 \mathrm{~h}$ (Atkinson, 2000) isoprene sources must have been at a maximum distance of $11 \mathrm{~km}$ from MSY. Following this reasoning, in summer part of the isoprene at MSY may have also been anthropogenic, however the biogenic contribution either from distant vegetation (advected, see Filella and Peñuelas, 2006) and from valley (local) isoprene-emitting species other than $Q$. ilex would have been greater. Moreover, isoprene in summer did not 
follow so closely the daily cycles of aromatics or ox VOCs as in winter, and instead had an earlier rise in mixing ratios, at the same time as monoterpenes did (Fig. 8). This may clearly indicate isoprene's summertime local biotic origin, at least in part. In contrast, most other VOCs including isoprene's oxidation products MVK and MACR started to rise collectively with a certain delay, when air masses advected by the sea breeze contributed to the VOC burden at MSY.

The only two other VOCs that also showed a summertime early rise in the morning were methanol and toluene. On the one hand, methanol has been reported to build up inside the leaves of plants when stomata remain closed during the night, and then burst out when they open in the morning. This phenomenon is under the control of the gas-liquid phase equilibrium of the alcohol within the leaf and of the stomatal conductance (Filella and Peñuelas, 2006; Filella et al., 2009; Niinemets and Reichstein, 2003). Some authors described this morning burst in mixing ratios, and attributed it to this stomata-related response and to the evaporation of dew, supposing that methanol may be dissolved in it (Filella and Peñuelas, 2006; Holzinger et al., 2001b; Sanhueza et al., 2001; Warneke et al., 2002). This morning burst is normally a short term pulse of emission followed by a longer decay. It is likely that the pattern in the mixing ratios showed in Fig. 8 results first from this short term emission pulse, and that later the longer decay gets masked by the arrival of a much higher methanol amount advected by the wind from the plains below the MSY station. On the other hand, toluene has been reported to be emitted by plants (Heiden et al., 1999; White et al., 2009) and emissions of $m / z, 93$ have been reported for Q. ilex and attributed to toluene (Holzinger et al., 2000). However, the possibility that certain monoterpene fragments may contribute to $m / z 93$ and thus being mistaken for toluene has been suggested (Kim et al., 2010). Notwithstanding, Ambrose et al. (2010) have recently reported this interference to be practically insignificant, so the early morning toluene increase must be product of either toluene emissions from plants or from a local anthropic source.

The high influence of the wind regime on VOC mixing ratios at MSY is illustrated by Fig. 9, which contains the same information as Fig. 8 but corresponds only to the 6 August, as representative for the atmospheric conditions of a number of days. On 6 August all VOCs, including monoterpenes, saw a reduction in mixing ratios when at around 14:00-15:00 $\mathrm{h}$ the wind started to change speed and moreover change direction, turning from SE (around 120 degrees) to W (260270 degrees). Solar radiation did not change (e.g. due to clouds), so it is probable that local biogenic emissions did not decrease. This VOC mixing ratio reduction occurred simultaneously with a reduction in $\mathrm{NO}_{2}$ levels and a small increase in $\mathrm{O}_{3}$ concentration. At around 17:00 h the wind went back to SE direction briefly and then changed at 18:00 h to $\mathrm{N}$ for the whole night. $\mathrm{VOC}$ and $\mathrm{NO}_{2}$ concentrations increased again when the wind direction returned to the SE direction, and sharply decreased when it changed to N. The SE
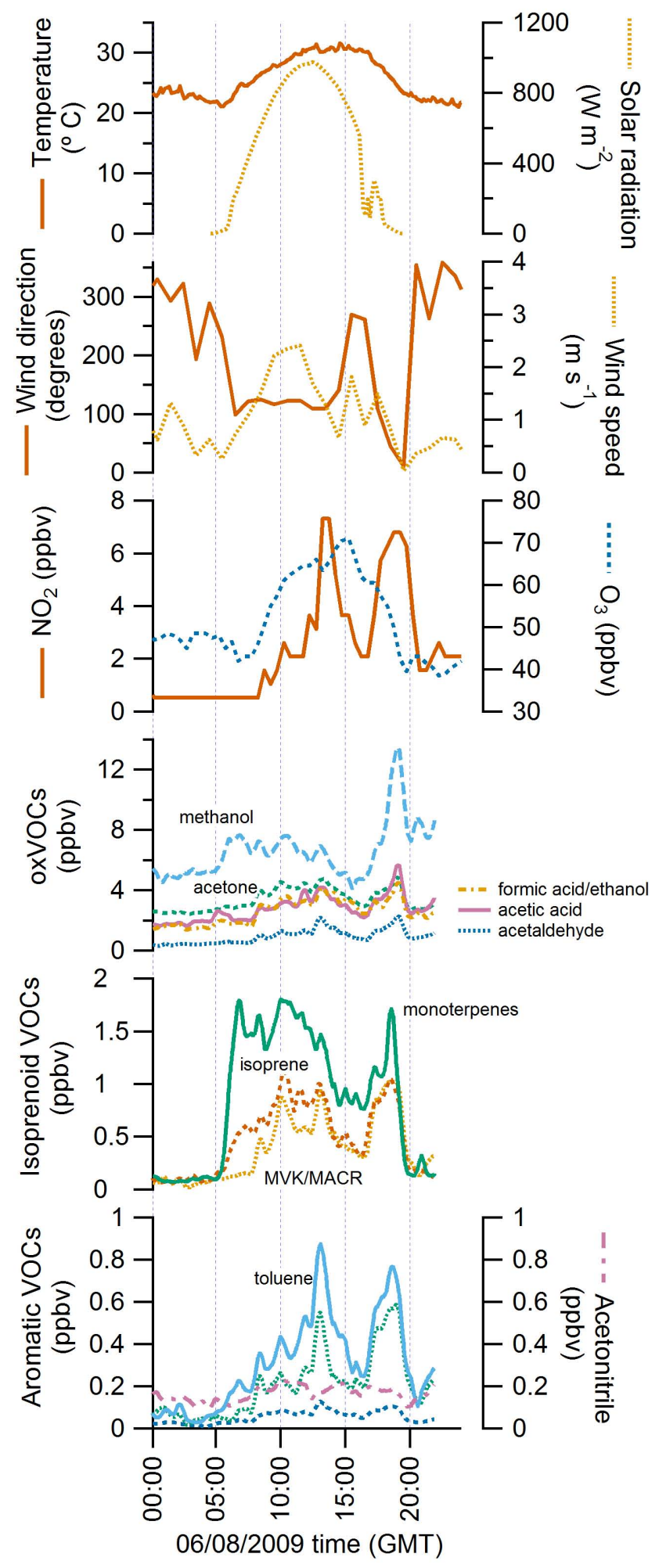

Fig. 9. Daily cycles of the majority of the variables studied, corresponding to the 6 August 2009. Panels and traces are the same as in Fig. 8. 
Table 3. VOC mixing ratios (ppbv) reported in the literature for several natural environments (either Scandinavian ecosystems, other mixed forests and rural sites, or Mediterranean ecosystems). Numbers represent means or medians, while numbers in brackets represent maximum values reported by the authors. The numbers are followed by a letter to indicate the time of year when they were recorded (w for winter, $\mathrm{s}$ for summer). The Castelporziano Mediterranean values were obtained in May-June.

\begin{tabular}{|c|c|c|c|c|c|c|c|c|c|c|}
\hline Location & methanol & acetone & acetaldehyde & isoprene & monoterpenes & MVK/MACR & benzene & toluene & $\begin{array}{l}\mathrm{C} 8- \\
\text { aromatics }\end{array}$ & References \\
\hline \multirow[t]{3}{*}{$\begin{array}{l}\text { Hyytiälä forest } \\
\text { (S Finland) }\end{array}$} & $\begin{array}{l}<0.7 \mathrm{w} \\
2 \mathrm{~s}\end{array}$ & $\begin{array}{l}<0.5 \mathrm{w} \\
(4.5 \mathrm{~s}) \\
1.5-1.7 \mathrm{~s}\end{array}$ & $\begin{array}{l}0.16- \\
0.33 \mathrm{w} \\
0.3 \mathrm{~s}\end{array}$ & $\begin{array}{l}0.06 \mathrm{w} \\
(0.5 \mathrm{~s}) \\
0.14-0.2 \mathrm{~s}\end{array}$ & $\begin{array}{l}<0.1 \mathrm{w} \\
0.25-0.3 \mathrm{~s}\end{array}$ & & & & & ${ }^{1}$ Lappalainen et al. (2009) \\
\hline & $\begin{array}{l}0.22 \mathrm{w} \\
1.9-3 \mathrm{~s}\end{array}$ & $\begin{array}{l}0.33 \mathrm{w} \\
1.35- \\
2.05 \mathrm{~s}\end{array}$ & $\begin{array}{l}0.16 \mathrm{w} \\
0.25- \\
0.39 \mathrm{~s}\end{array}$ & $\begin{array}{l}0.05 \mathrm{w} \\
0.14-0.17 \mathrm{~s}\end{array}$ & $\begin{array}{l}0.05-0.09 \mathrm{w} \\
0.29-0.37 \mathrm{~s}\end{array}$ & $\begin{array}{l}0.07 \mathrm{w} \\
0.12-0.16 \mathrm{~s}\end{array}$ & $\begin{array}{l}0.14 \mathrm{w} \\
0.04- \\
0.07 \mathrm{~s}\end{array}$ & & & Ruuskanen et al. (2009) \\
\hline & $\begin{array}{l}3.5 \mathrm{~s} \\
(8.5 \mathrm{~s})\end{array}$ & $\begin{array}{l}1.5 \mathrm{~s} \\
(3.5 \mathrm{~s})\end{array}$ & $\begin{array}{l}1 \mathrm{~s} \\
(1.9 \mathrm{~s})\end{array}$ & $\begin{array}{l}0.1 \mathrm{~s} \\
(0.3 \mathrm{~s})\end{array}$ & $\begin{array}{l}<1 \mathrm{~s} \\
(2.5 \mathrm{~s})\end{array}$ & $\begin{array}{l}0.1 \mathrm{~s} \\
(0.2 \mathrm{~s})\end{array}$ & $\begin{array}{l}<0.05 \mathrm{~s} \\
(0.09 \mathrm{~s})\end{array}$ & & & ${ }^{2}$ Rinne et al. (2005) \\
\hline $\begin{array}{l}\text { sub-arctic wetland } \\
\text { (N Sweden) }\end{array}$ & $\begin{array}{l}2.8 \mathrm{~s} \\
(6 \mathrm{~s})\end{array}$ & $\begin{array}{l}1 \mathrm{~s} \\
(2.1 \mathrm{~s})\end{array}$ & $\begin{array}{l}0.2 \mathrm{~s} \\
(0.5 \mathrm{~s})\end{array}$ & $\begin{array}{l}0.38 \mathrm{~s} \\
(1.2 \mathrm{~s})\end{array}$ & & & & & & Holst et al. (2010) \\
\hline $\begin{array}{l}\text { rural site with } \\
\text { urban influences } \\
\text { (New Hampshire, } \\
\text { USA) }\end{array}$ & $\begin{array}{l}0.97 \mathrm{w} \\
2.69 \mathrm{~s}\end{array}$ & $\begin{array}{l}0.57 \mathrm{w} \\
2.11 \mathrm{~s}\end{array}$ & $\begin{array}{l}0.33 \mathrm{w} \\
0.54 \mathrm{~s}\end{array}$ & $\begin{array}{l}0.05 \mathrm{w} \\
0.42 \mathrm{~s}\end{array}$ & $\begin{array}{l}0.10 \mathrm{w} \\
0.50 \mathrm{~s}\end{array}$ & $\begin{array}{l}0.04 \mathrm{w} \\
0.33 \mathrm{~s}\end{array}$ & $\begin{array}{l}0.20 \mathrm{w} \\
0.08 \mathrm{~s}\end{array}$ & $\begin{array}{l}0.11 \mathrm{w} \\
0.14 \mathrm{~s}\end{array}$ & $\begin{array}{l}0.10 \mathrm{w} \\
0.12 \mathrm{~s}\end{array}$ & Jordan et al. (2009) \\
\hline $\begin{array}{l}\text { mixed forest } \\
\text { (Michigan, USA) }\end{array}$ & & & & $2 \mathrm{~s}$ & $\begin{array}{l}0.25 \mathrm{~s} \\
(0.97 \mathrm{~s})\end{array}$ & & & & & ${ }^{1}$ Mielke et al. (2010) \\
\hline $\begin{array}{l}\text { mixed deciduous } \\
\text { forest (Jülich, NW } \\
\text { Germany) }\end{array}$ & $13 \mathrm{~s}(22 \mathrm{~s})$ & & & $\begin{array}{l}2 \mathrm{~s} \\
(9 \mathrm{~s})\end{array}$ & $\begin{array}{l}0.5 \mathrm{~s} \\
(1 \mathrm{~s})\end{array}$ & $\begin{array}{l}0.4 \mathrm{~s} \\
(1.2 \mathrm{~s})\end{array}$ & & & & ${ }^{1,2}$ Spirig et al. (2005) \\
\hline $\begin{array}{l}\text { urban-impacted } \\
\text { forest (Germany) }\end{array}$ & & & & $(0.2-1.5 \mathrm{~s})$ & & & $(0.5-2 \mathrm{~s})$ & $(0.2-1.5 \mathrm{~s})$ & $(0.5-1.5 \mathrm{~s})$ & ${ }^{2}$ Steinbrecher et al. (2000) \\
\hline \multirow{2}{*}{$\begin{array}{l}\text { Castelporziano } \\
\text { Mediterranean } \\
\text { ecosystem (Italy) }\end{array}$} & & 1.74 & 1.80 & $0.17-0.376$ & & & 0.64 & 0.89 & & ${ }^{1}$ Kalabokas et al. (1997) \\
\hline & $1.6-3.5$ & $0.96-2.1$ & $0.44-1.3$ & $0.1-0.14$ & $0.13-0.30$ & & & & & Davison et al. (2009) \\
\hline $\begin{array}{l}\text { Montseny } \\
\text { (NE Spain) }\end{array}$ & $\begin{array}{l}1.84 \mathrm{w} \\
(9.76 \mathrm{w}) \\
4.92 \mathrm{~s} \\
(13.4 \mathrm{~s})\end{array}$ & $\begin{array}{l}1.1 \mathrm{w} \\
(3.9 \mathrm{w}) \\
2.76 \mathrm{~s} \\
(5.95 \mathrm{~s})\end{array}$ & $\begin{array}{l}0.4 \mathrm{w} \\
(1.88 \mathrm{w}) \\
0.78 \mathrm{~s} \\
(3.37 \mathrm{~s})\end{array}$ & $\begin{array}{l}0.04 \mathrm{w} \\
(0.18 \mathrm{w}) \\
0.43 \mathrm{~s} \\
(1.25 \mathrm{~s})\end{array}$ & $\begin{array}{l}0.03 \mathrm{w} \\
(0.23 \mathrm{w}) \\
0.64 \mathrm{~s} \\
(2.56 \mathrm{~s})\end{array}$ & $\begin{array}{l}0.02 \mathrm{w} \\
(0.15 \mathrm{w}) \\
0.32 \mathrm{~s} \\
(1.04 \mathrm{~s})\end{array}$ & $\begin{array}{l}0.13 \mathrm{w} \\
(0.47 \mathrm{w}) \\
0.05 \mathrm{~s} \\
(0.19 \mathrm{~s})\end{array}$ & $\begin{array}{l}0.18 \mathrm{w} \\
(1.9 \mathrm{w}) \\
0.23 \mathrm{~s} \\
(1.34 \mathrm{~s})\end{array}$ & $\begin{array}{l}0.1 \mathrm{w} \\
(1.33 \mathrm{w}) \\
0.17 \mathrm{~s} \\
(0.82 \mathrm{~s})\end{array}$ & This study \\
\hline
\end{tabular}

${ }^{1}$ These values correspond only to day-time or midday hours. ${ }^{2}$ Approximate values taken from graphs.

wind direction corresponded to the usual sea breeze that occurs at MSY, with the wind coming valley upwards from the Barcelona metropolitan region. When the wind was blowing from the $\mathrm{W}$, the air was coming from another valley, and although $Q$. ilex is the dominant plant species there too, before arriving at the MSY site the air passed over Pla de la Calma (1100-1300 ma.s.1.), a plateau covered by heath communities of Calluna vulgaris, Pteridium aquilinum, Festuca ovina, and Scleranthus annuus (Bolòs, 1983). This different vegetation, much less dense, with less biomass, and with isoprenoid emission factors reported to be lower (Hewitt and Street, 1992), emits much less VOCs than the holm oak forests of the SE valley.

\subsection{Comparison with VOC mixing ratios reported in the literature}

Data on VOC mixing ratios from several other natural environments have also been reported (see Table 3 and the Supplement). In general, in Nordic environments oxVOC and isoprenoid mixing ratios were lower than those measured at MSY, with only some occasional peaks higher than at MSY (Holst et al., 2010; Lappalainen et al., 2009; Rinne et al., 2005; Ruuskanen et al., 2009). These results are in accordance with the lower physiological activity of the vegetation in Nordic regions linked to lower temperatures, thus resulting in lower emissions compared to the Mediterranean MSY. In a rural area near the coast in New Hampshire (East USA), the ox VOC mixing ratios were also generally lower than at MSY in both seasons, while isoprenoids were in the same range or slightly higher than at MSY (Jordan et al., 2009). A mixed forest in the northern USA presented lower monoterpene mixing ratios than at MSY in summer, but higher isoprene mixing ratios (Mielke et al., 2010). The same situation for monoterpenes and isoprene compared to MSY was found in a mixed forest in NW Germany in summer, where methanol presented higher mixing ratios too (Spirig et al., 2005).

The only reports related to typical Mediterranean ecosystems are those from the Castelporziano site (Italy), surrounded by $Q$. ilex forests and macchia, and also 
influenced by the urban environment of Rome. For the year 1994 and within the BEMA campaign, Kalabokas et al. (1997) described a lower daily mean acetone mixing ratio (1.74 ppbv) than in MSY summer. However, that campaign was held in May and this mixing ratio is, accordingly, between our MSY winter and summer values. In contrast, the daily average mixing ratios of acetaldehyde (1.8 ppbv) were above those registered at MSY. More recently in 2007, Davison et al. (2009) took measurements again at the same site and period (May-June). The reported mixing ratios of methanol (medians of 1.6 to $3.5 \mathrm{ppbv}$ ) and again acetone (0.96-2.1 ppbv) were in this case slightly lower than those at MSY, while acetaldehyde showed similar values (medians of 0.44-1.3 ppbv). Regarding isoprenoids, the Mediterranean site of Castelporziano showed slightly lower mixing ratios of isoprene (medians of $0.1-0.37 \mathrm{ppbv}$ ) and MVK/MACR (medians of 0.13-0.30 ppbv) and clearly lower monoterpene mixing ratios (medians of 0.13-0.3) in May than at MSY in summer (Davison et al., 2009; Kalabokas et al., 1997). As with oxVOCs, the results for isoprenoids in summer in Castelporziano may have been hypothetically closer to those from MSY, as these mixing ratios are somewhat in between the MSY winter and summer readings. Nevertheless summer drought may exert a big influence in VOC emissions in Castelporziano and have the contrary effect, as the authors pointed out when choosing the period for measurements (they considered that plants would have good temperature and water conditions for VOC emission in May-June).

An interesting detail is that the maximum monoterpene mixing ratios in the 2007 Castelporziano campaign were detected at night, when the land breeze originated and air was coming from oak and pine forests. These mixing ratios were higher (medians of 0.26 to $0.57 \mathrm{ppbv}$ ) than the night ones at MSY. The authors attributed this behaviour to the nighttime temperature-dependent emissions of stored monoterpenes by the pines together with the cessation of photochemical destruction of VOCs and the suppression of vertical mixing at night (Davison et al., 2009). In MSY, vertical mixing and photochemistry were also suppressed at night, but the land breeze acted in the contrary sense, cleaning the air from VOCs. This may be in part due to the fact that there are no significant tree populations in the surroundings that could emit monoterpenes from storage pools at night, as holm oaks do not store monoterpenes. Rather they emit them from de novo synthesis, influenced by temperature, irradiance and water availability (Llusià and Peñuelas, 1999; Loreto et al., 1998; Peñuelas and Llusià, 1999b; Staudt et al., 2002). It should be noted that some forest measurements at Hyytiälä, Finland (Rinne et al., 2005; Ruuskanen et al., 2009), at a rural location in New Hampshire, USA (Jordan et al., 2009) and at a mixed forest in Germany (Mielke et al., 2010) also reported higher monoterpene mixing ratios in summer at night.

\section{Summary and conclusions}

VOC mixing ratio measurements in an elevated Mediterranean forested site (MSY) with a dense vegetation dominated by Quercus ilex were performed. There were two sets of measures, one in winter (February-March) and another in summer (July-August). While aromatic VOCs showed almost no seasonal variability (only benzene had lower summer mixing ratios), short-chain oxygenated VOCs presented higher mixing ratios in summer, presumably due to the increased emission by vegetation and increased photochemistry, both enhanced by the high temperatures and solar radiation in summer. Methanol was the most abundant compound among all the VOCs measured in both seasons.

Isoprenoid VOCs (monoterpenes and isoprene, and its oxidation products MVK/MACR) were involved in the biggest change in mixing ratios between winter and summer. That is, their mixing ratios increased by one order of magnitude, as a result of the increased physiological activity and emission rates of the vegetation. The highest diurnal concentrations of ozone increased in summer too, most likely due to more intense photochemical activity and the presence of more reactive VOCs in the air.

VOC mixing ratios analysis at the MSY forest site in the Western Mediterranean Basin showed that their diel variation is mainly governed by the wind regime of the mountain, since the majority of the VOC species analyzed followed a very similar daily cycle. Sea and mountain breezes that develop after sunrise advect polluted air masses to the mountain that previously had passed over the Barcelona metropolitan region, where they were enriched in $\mathrm{NO}_{\mathrm{x}}$ and in VOCs of anthropic and biotic origin. Furthermore, these polluted air masses can react with biogenic VOCs emitted at the MSY valley by the vegetation, thus enhancing $\mathrm{O}_{3}$ formation in this mountain site. The only VOC species that showed a distinct different daily pattern - though still affected by the wind regime - were monoterpenes, because they were emitted by the local vegetation of the valley. Isoprene also shared partially the diel pattern of the monoterpenes, but only in summer when its biotic sources were stronger. These high concentrations of biogenic volatile isoprenoids indicate the significant impact of local forested vegetation on air quality in these Mediterranean areas which also receive polluted air masses from anthropic sources.

\section{Supplementary material related to this article is available online at: http://www.atmos-chem-phys.net/11/13161/2011/ acp-11-13161-2011-supplement.pdf.}

Acknowledgements. This study was supported by the Spanish Government grants CGL2006-04025/BOS, CGL2010-17172, Consolider-Ingenio Montes CSD2008-00040 and Acción Complementaria DAURE CGL2007-30502-E/CLI, and the Catalan Government grant SGR 2009-458. Roger Seco was partially supported 
by an FPI fellowship (BES-2005-6989) from the Spanish Government and by a postdoctoral grant from Fundación Ramón Areces.

This research has received funding from the EC Seventh Framework Programme under grant agreement no. 215072 (Marie Curie Initial Training Network, "CLOUD-ITN"). Helpful discussion concerning the PTR-TOF evaluation with Martin Graus and Ralf Schnitzhofer from the University of Innsbruck was much appreciated. The authors are also grateful to Xavier Querol and Andrés Alastuey for fruitful comments on earlier versions of this manuscript and for organizing the DAURE campaign.

The National Center for Atmospheric Research is sponsored by the National Science Foundation.

Edited by: A. Hofzumahaus

\section{References}

Ambrose, J. L., Haase, K., Russo, R. S., Zhou, Y., White, M. L., Frinak, E. K., Jordan, C., Mayne, H. R., Talbot, R., and Sive, B. C.: A comparison of GC-FID and PTR-MS toluene measurements in ambient air under conditions of enhanced monoterpene loading, Atmos. Meas. Tech., 3, 959-980, doi:10.5194/amt-3959-2010, 2010.

Arneth, A., Harrison, S. P., Zaehle, S., Tsigaridis, K., Menon, S., Bartlein, P. J., Feichter, J., Korhola, A., Kulmala, M., O’Donnell, D., Schurgers, G., Sorvari, S., and Vesala, T.: Terrestrial biogeochemical feedbacks in the climate system, Nat. Geosci., 3, 525532, 2010.

Atkinson, R.: Atmospheric chemistry of VOCs and $\mathrm{NO}_{\mathrm{x}}$, Atmos. Environ., 34, 2063-2101, 2000.

Avila, A. and Alarcon, M.: Precipitation chemistry at a rural Mediterranean site: Between anthropogenic pollution and natural emissions, J. Geophys. Res.-Atmos., 108, 4278, doi:10.1029/2002JD002565, 2003.

Avila, A. and Rodà, F.: Assessing decadal changes in rainwater alkalinity at a rural Mediterranean site in the Montseny Mountains (NE Spain), Atmos. Environ., 36, 2881-2890, 2002.

Avila, A. and Rodrigo, A.: Trace metal fluxes in bulk deposition, throughfall and stemflow at two evergreen oak stands in NE Spain subject to different exposure to the industrial environment, Atmos. Environ., 38, 171-180, 2004.

Avila, A., Alarcon, M., and Queralt, I.: The chemical composition of dust transported in red rains - Its contribution to the biogeochemical cycle of a Holm oak forest in Catalonia (Spain), Atmos. Environ., 32, 179-191, 1998.

Avila, A., Rodrigo, A., and Rodà, F.: Nitrogen circulation in a Mediterranean holm oak forest, La Castanya, Montseny, northeastern Spain, Hydrol. Earth Syst. Sci., 6, 551-558, doi:10.5194/hess-6-551-2002, 2002.

Avila, A., Alarcon, M., Castillo, S., Escudero, M., Garcia-Orellana, J., Masque, P., and Querol, X.: Variation of soluble and insoluble calcium in red rains related to dust sources and transport patterns from North Africa to northeastern Spain, J. Geophys. Res.-Atmos., 112, D05210, doi:10.1029/2006JD007153, 2007.

Avila, A., Molowny-Horas, R., Gimeno, B. S., and Peñuelas, J.: Analysis of Decadal Time Series in Wet N Concentrations at Five Rural Sites in NE Spain, Water Air Soil Pollut., 207, 123-138, 2010 .
Baldwin, I. T., Halitschke, R., Paschold, A., von Dahl, C. C., and Preston, C. A.: Volatile signaling in plant-plant interactions: "Talking trees" in the genomics era, Science, 311, 812-815, 2006.

Bolòs, O.: La vegetació del Montseny, Diputació de Barcelona, Barcelona, 1983.

Borbon, A., Fontaine, H., Veillerot, M., Locoge, N., Galloo, J. C., and Guillermo, R.: An investigation into the traffic-related fraction of isoprene at an urban location, Atmos. Environ., 35, 37493760, 2001.

Calfapietra, C., Fares, S., and Loreto, F.: Volatile organic compounds from Italian vegetation and their interaction with ozone, Environ. Pollut., 157, 1478-1486, 2009.

Davison, B., Taipale, R., Langford, B., Misztal, P., Fares, S., Matteucci, G., Loreto, F., Cape, J. N., Rinne, J., and Hewitt, C. N.: Concentrations and fluxes of biogenic volatile organic compounds above a Mediterranean macchia ecosystem in western Italy, Biogeosciences, 6, 1655-1670, doi:10.5194/bg-6-16552009, 2009.

de Gouw, J. and Warneke, C.: Measurements of volatile organic compounds in the Earth's atmosphere using proton-transferreaction mass spectrometry, Mass Spectrom. Rev., 26, 223-257, 2007.

Diaz-de-Quijano, M., Peñuelas, J., and Ribas, A.: Increasing interannual and altitudinal ozone mixing ratios in the Catalan Pyrenees, Atmos. Environ., 43, 6049-6057, 2009.

Evtyugina, M. G., Nunes, T., Alves, C., and Marques, M. C.: Photochemical pollution in a rural mountainous area in the northeast of Portugal, Atmos. Res., 92, 151-158, 2009.

Filella, I. and Peñuelas, J.: Daily, weekly, and seasonal time courses of VOC concentrations in a semi-urban area near Barcelona, Atmos. Environ., 40, 7752-7769, 2006.

Filella, I., Peñuelas, J., and Seco, R.: Short-chained oxygenated VOC emissions in Pinus halepensis in response to changes in water availability, Acta Physiol. Plant., 31, 311-318, doi:10.1007/s11738-008-0235-6, 2009.

Fowler, D., Pilegaard, K., Sutton, M. A., Ambus, P., Raivonen, M., Duyzer, J., Simpson, D., Fagerli, H., Fuzzi, S., Schjoerring, J. K., Granier, C., Neftel, A., Isaksen, I. S. A., Laj, P., Maione, M., Monks, P. S., Burkhardt, J., Daemmgen, U., Neirynck, J., Personne, E., Wichink-Kruit, R., Butterbach-Bahl, K., Flechard, C., Tuovinen, J. P., Coyle, M., Gerosa, G., Loubet, B., Altimir, N., Gruenhage, L., Ammann, C., Cieslik, S., Paoletti, E., Mikkelsen, T. N., Ro-Poulsen, H., Cellier, P., Cape, J. N., Horvath, L., Loreto, F., Niinemets, Ü., Palmer, P. I., Rinne, J., Misztal, P., Nemitz, E., Nilsson, D., Pryor, S., Gallagher, M. W., Vesala, T., Skiba, U., Brueggemann, N., Zechmeister-Boltenstern, S., Williams, J., O’Dowd, C., Facchini, M. C., de Leeuw, G., Flossman, A., Chaumerliac, N., and Erisman, J. W.: Atmospheric composition change: Ecosystems-Atmosphere interactions, Atmos. Environ., 43, 5193-5267, 2009.

Gimeno, B. S., Peñuelas, J., Porcuna, J. L., and Reinert, R. A.: Biomonitoring ozone phytotoxicity in eastern Spain, Water Air Soil Pollut., 85, 1521-1526, 1995.

Graus, M., Müller, M., and Hansel, A.: High Resolution PTR-TOF: Quantification and Formula Confirmation of VOC in Real Time, J. Am. Soc. Mass Spectrom., 21, 1037-1044, 2010.

Guenther, A., Hewitt, C. N., Erickson, D., Fall, R., Geron, C., Graedel, T., Harley, P., Klinger, L., Lerdau, M., Mckay, W. A., 
Pierce, T., Scholes, B., Steinbrecher, R., Tallamraju, R., Taylor, J., and Zimmerman, P.: A Global-Model of Natural Volatile Organic-Compound Emissions, J. Geophys. Res., 100, 88738892, 1995.

Guenther, A., Karl, T., Harley, P., Wiedinmyer, C., Palmer, P. I., and Geron, C.: Estimates of global terrestrial isoprene emissions using MEGAN (Model of Emissions of Gases and Aerosols from Nature), Atmos. Chem. Phys., 6, 3181-3210, doi:10.5194/acp-63181-2006, 2006.

Heiden, A. C., Kobel, K., Komenda, M., Koppmann, R., Shao, M., and Wildt, J.: Toluene emissions from plants, Geophys. Res. Lett., 26, 1283-1286, 1999.

Hewitt, C. N. and Street, R. A.: A qualitative assessment of the emission of non-methane hydrocarbon compounds from the biosphere to the atmosphere in the UK: present knowledge and uncertainties, Atmos. Environ. A-Gen., 26, 3069-3077, 1992.

Hewitt, C. N., Ashworth, K., Boynard, A., Guenther, A., Langford, B., MacKenzie, A. R., Misztal, P. K., Nemitz, E., Owen, S. M., Possell, M., Pugh, T. A. M., Ryan, A. C., and Wild, O.: Ground-level ozone influenced by circadian control of isoprene emissions, Nat. Geosci., 4, 671-674, 2011.

Holst, T., Arneth, A., Hayward, S., Ekberg, A., Mastepanov, M., Jackowicz-Korczynski, M., Friborg, T., Crill, P. M., and Bäckstrand, K.: BVOC ecosystem flux measurements at a high latitude wetland site, Atmos. Chem. Phys., 10, 1617-1634, doi:10.5194/acp-10-1617-2010, 2010.

Holzinger, R., Warneke, C., Hansel, A., Jordan, A., Lindinger, W., Scharffe, D. H., Schade, G., and Crutzen, P. J.: Biomass burning as a source of formaldehyde, acetaldehyde, methanol, acetone, acetonitrile, and hydrogen cyanide, Geophys. Res. Lett., 26, 1161-1164, 1999.

Holzinger, R., Sandoval-Soto, L., Rottenberger, S., Crutzen, P. J., and Kesselmeier, J.: Emissions of volatile organic compounds from Quercus ilex L. measured by Proton Transfer Reaction Mass Spectrometry under different environmental conditions, J. Geophys. Res., 105, 20573-20579, 2000.

Holzinger, R., Jordan, A., Hansel, A., and Lindinger, W.: Automobile emissions of acetonitrile: Assessment of its contribution to the global source, J. Atmos. Chem., 38, 187-193, 2001a.

Holzinger, R., Jordan, A., Hansel, A., and Lindinger, W.: Methanol measurements in the lower troposphere near Innsbruck (047 degrees 16'N; 011 degrees 24'E), Austria, Atmos. Environ., 35, 2525-2532, 2001b.

Jacob, D. J., Field, B. D., Li, Q. B., Blake, D. R., de Gouw, J., Warneke, C., Hansel, A., Wisthaler, A., Singh, H. B., and Guenther, A.: Global budget of methanol: Constraints from atmospheric observations, J. Geophys. Res., 110, D08303, doi:10.1029/2004JD005172, 2005.

Jorba, O., Pandolfi, M., Spada, M., Baldasano, J. M., Pey, J., Alastuey, A., Arnold, D., Sicard, M., Artiñano, B., Revuelta, M. A., and Querol, X.: The DAURE field campaign: meteorological overview, Atmos. Chem. Phys. Discuss., 11, 4953-5001, doi:10.5194/acpd-11-4953-2011, 2011.

Jordan, C., Fitz, E., Hagan, T., Sive, B., Frinak, E., Haase, K., Cottrell, L., Buckley, S., and Talbot, R.: Long-term study of VOCs measured with PTR-MS at a rural site in New Hampshire with urban influences, Atmos. Chem. Phys., 9, 4677-4697, doi:10.5194/acp-9-4677-2009, 2009.

Kalabokas, P., Bartzis, J. G., Bomboi, T., Ciccioli, P., Cieslik, S.,
Dlugi, R., Foster, P., Kotzias, D., and Steinbrecher, R.: Ambient atmospheric trace gas concentrations and meteorological parameters during the first BEMA measuring campaign on May 1994 at Castelporziano, Italy, Atmos. Environ., 31, 67-77, 1997.

Karl, T., Guenther, A., Jordan, A., Fall, R., and Lindinger, W.: Eddy covariance measurement of biogenic oxygenated VOC emissions from hay harvesting, Atmos. Environ., 35, 491-495, 2001.

Karl, T., Hansel, A., Mark, T., Lindinger, W., and Hoffmann, D.: Trace gas monitoring at the Mauna Loa Baseline observatory using proton-transfer reaction mass spectrometry, Int. J. Mass Spectrom., 223, 527-538, 2003.

Kavouras, I. G., Mihalopoulos, N., and Stephanou, E. G.: Formation of atmospheric particles from organic acids produced by forests, Nature, 395, 683-686, 1998.

Kegge, W. and Pierik, R.: Biogenic volatile organic compounds and plant competition, Trends Plant Sci., 15, 126-132, 2010.

Kessler, A. and Baldwin, I. T.: Defensive function of herbivoreinduced plant volatile emissions in nature, Science, 291, 21412144, 2001.

Kim, S., Karl, T., Guenther, A., Tyndall, G., Orlando, J., Harley, P., Rasmussen, R., and Apel, E.: Emissions and ambient distributions of Biogenic Volatile Organic Compounds (BVOC) in a ponderosa pine ecosystem: interpretation of PTR-MS mass spectra, Atmos. Chem. Phys., 10, 1759-1771, doi:10.5194/acp-10-17592010, 2010.

Kulmala, M., Suni, T., Lehtinen, K. E. J., Dal Maso, M., Boy, M., Reissell, A., Rannik, Ü., Aalto, P., Keronen, P., Hakola, H., Bäck, J., Hoffmann, T., Vesala, T., and Hari, P.: A new feedback mechanism linking forests, aerosols, and climate, Atmos. Chem. Phys., 4, 557-562, doi:10.5194/acp-4-557-2004, 2004.

Lappalainen, H. K., Sevanto, S., Bäck, J., Ruuskanen, T. M., Kolari, P., Taipale, R., Rinne, J., Kulmala, M., and Hari, P.: Day-time concentrations of biogenic volatile organic compounds in a boreal forest canopy and their relation to environmental and biological factors, Atmos. Chem. Phys., 9, 5447-5459, doi:10.5194/acp-9-5447-2009, 2009.

Lindinger, W., Hansel, A., and Jordan, A.: On-line monitoring of volatile organic compounds at pptv levels by means of protontransfer-reaction mass spectrometry (PTR-MS) - Medical applications, food control and environmental research, Int. J. Mass Spectrom., 173, 191-241, 1998.

Lippmann, M.: Health-Effects of Tropospheric Ozone - Review of Recent Research Findings and their Implications to Ambient AirQuality Standards, J. Expo. Anal. Environ. Epidemiol., 3, 103129, 1993.

Llusià, J. and Peñuelas, J.: Pinus halepensis and Quercus ilex terpene emission as affected by temperature and humidity, Biol Plantarum, 42, 317-320, 1999.

Llusià, J. and Peñuelas, J.: Seasonal patterns of terpene content and emission from seven Mediterranean woody species in field conditions, Am. J. Bot., 87, 133-140, 2000.

Llusià, J. and Peñuelas, J.: Emission of volatile organic compounds by apple trees under spider mite attack and attraction of predatory mites, Exp. Appl. Acarol., 25, 65-77, 2001.

Llusià, J., Peñuelas, J., Sardans, J., Owen, S. M., and Niinemets, Ü.: Measurement of volatile terpene emissions in 70 dominant vascular plant species in Hawaii: aliens emit more than natives, Global Ecol. Biogeogr., 19, 863-874, 2010.

Llusià J., Peñuelas J., Seco R., and Filella I. Seasonal changes in 
the daily emission rates of terpenes by Quercus ilex and the atmospheric concentrations of terpenes in the natural park of Montseny, NE Spain, in preparation, 2011.

Loreto, F., Ciccioli, P., Brancaleoni, E., Valentini, R., De Lillis, M., Csiky, O., and Seufert, G.: A hypothesis on the evolution of isoprenoid emission by oaks based on the correlation between emission type and Quercus taxonomy, Oecologia, 115, 302-305, 1998.

Mielke, L. H., Pratt, K. A., Shepson, P. B., McLuckey, S. A., Wisthaler, A., and Hansel, A.: Quantitative Determination of Biogenic Volatile Organic Compounds in the Atmosphere Using Proton-Transfer Reaction Linear Ion Trap Mass Spectrometry, Anal. Chem., 82, 7952-7957, 2010.

Minguillón, M. C., Perron, N., Querol, X., Szidat, S., Fahrni, S. M., Alastuey, A., Jimenez, J. L., Mohr, C., Ortega, A. M., Day, D. A., Lanz, V. A., Wacker, L., Reche, C., Cusack, M., Amato, F., Kiss, G., Hoffer, A., Decesari, S., Moretti, F., Hillamo, R., Teinilä, K., Seco, R., Peñuelas, J., Metzger, A., Schallhart, S., Müller, M., Hansel, A., Burkhart, J. F., Baltensperger, U., and Prévôt, A. S. H.: Fossil versus contemporary sources of fine elemental and organic carbonaceous particulate matter during the DAURE campaign in Northeast Spain, Atmos. Chem. Phys., 11, 1206712084, doi:10.5194/acp-11-12067-2011, 2011.

Müller, M., Graus, M., Ruuskanen, T. M., Schnitzhofer, R., Bamberger, I., Kaser, L., Titzmann, T., Hörtnagl, L., Wohlfahrt, G., Karl, T., and Hansel, A.: First eddy covariance flux measurements by PTR-TOF, Atmos. Meas. Tech., 3, 387-395, doi:10.5194/amt-3-387-2010, 2010.

Niinemets, Ü. and Reichstein, M.: Controls on the emission of plant volatiles through stomata: Differential sensitivity of emission rates to stomatal closure explained, J. Geophys. Res., 108, 4208, doi:10.1029/2002JD002620, 2003.

Pacifico, F., Harrison, S. P., Jones, C. D., and Sitch, S.: Isoprene emissions and climate, Atmos. Environ., 43, 6121-6135, 2009.

Pandolfi, M., Querol, X., Alastuey, A., Jimenez, J. L., Cusack, M., Reche, C., Pey, J., Mohr, C., DeCarlo, P., Prévôt, A., Baltensperger, U., Artiñano, B., Baldasano, J. M., Jorba, O., Burkhart, J., Hansel, A., Schallhart, S., Müller, M., Metzger, A., Ortega, A., Saarikoski, S., Cubison, M., Ng, S., Lorente, J., Nemitz, E., di Marco, C., Peñuelas, J., Sicard, M., Comeron, A., Amato, F., Moreno, T., Viana, M., Pérez, N., Moreno, N., Seco, R., Filella, I., Llusià, J., Piot, M., and Pay, M. T.: Source and origin of PM in the Western Mediterranean Basin: An overview of the DAURE campaign. Atmos. Chem. Phys. Discuss., in preparation, 2011.

Peñuelas, J. and Llusià, J.: Seasonal emission of monoterpenes by the Mediterranean tree Quercus ilex in field conditions: Relations with photosynthetic rates, temperature and volatility, Physiol. Plant., 105, 641-647, 1999a.

Peñuelas, J. and Llusià, J.: Short-term responses of terpene emission rates to experimental changes of PFD in Pinus halepensis and Quercus ilex in summer field conditions, Environ. Exp. Bot., 42, 61-68, 1999b.

Peñuelas, J. and Llusià, J.: Linking photorespiration, monoterpenes and thermotolerance in Quercus, New Phytol., 155, 227-237, 2002.

Peñuelas, J. and Munné-Bosch, S.: Isoprenoids: an evolutionary pool for photoprotection, Trends Plant Sci., 10, 166-169, 2005.

Peñuelas, J. and Staudt, M.: BVOCs and global change, Trends
Plant Sci., 15, 133-144, 2010.

Peñuelas, J., Llusià, J., and Estiarte, M.: Terpenoids - a Plant Language, Trends Ecol. Evol., 10, 289-289, 1995.

Peñuelas, J., Llusià, J., Asensio, D., and Munné-Bosch, S.: Linking isoprene with plant thermotolerance, antioxidants and monoterpene emissions, Plant Cell Environ., 28, 278-286, 2005.

Peñuelas, J., Filella, I., Seco, R., and Llusià, J.: Increase in isoprene and monoterpene emissions after re-watering of droughted Quercus ilex seedlings, Biol. Plantarum, 53, 351-354, doi:10.1007/s10535-009-0065-4, 2009.

Pérez, N., Pey, J., Castillo, S., Viana, M., Alastuey, A., and Querol, $\mathrm{X}$.: Interpretation of the variability of levels of regional background aerosols in the Western Mediterranean, Sci. Total Environ., 407, 527-540, 2008.

Pey, J., Pérez, N., Castillo, S., Viana, M., Moreno, T., Pandolfi, M., Lopez-Sebastian, J. M., Alastuey, A., and Querol, X.: Geochemistry of regional background aerosols in the Western Mediterranean, Atmos. Res., 94, 422-435, 2009.

Piñol, J., Avila, A., Escarre, A., Lledo, M. J., and Rodà, F.: Comparison of the Hydrological Characteristics of 3 Small Experimental Holm Oak Forested Catchments in Ne Spain in Relation to Larger Areas, Vegetatio, 100, 169-176, 1992.

Possanzini, M., Di Palo, V., and Cecinato, A.: Sources and photodecomposition of formaldehyde and acetaldehyde in Rome ambient air, Atmos. Environ., 36, 3195-3201, 2002.

Ribas, A. and Peñuelas, J.: Temporal patterns of surface ozone levels in different habitats of the North Western Mediterranean basin, Atmos. Environ., 38, 985-992, 2004.

Ribas, A. and Peñuelas, J.: Surface ozone mixing ratio increase with altitude in a transect in the Catalan Pyrenees, Atmos. Environ., 40, 7308-7315, 2006.

Ribas, A., Peñuelas, J., Elvira, S., and Gimeno, B. S.: Ozone exposure induces the activation of leaf senescence-related processes and morphological and growth changes in seedlings of Mediterranean tree species, Environmental Pollution, 134, 291300, 2005.

Rinne, J., Ruuskanen, T. M., Reissell, A., Taipale, R., Hakola, H., and Kulmala, M.: On-line PTR-MS measurements of atmospheric concentrations of volatile organic compounds in a European boreal forest ecosystem, Boreal Environ. Res., 10, 425-436, 2005.

Ruuskanen, T. M., Taipale, R., Rinne, J., Kajos, M. K., Hakola, H., and Kulmala, M.: Quantitative long-term measurements of VOC concentrations by PTR-MS: annual cycle at a boreal forest site, Atmos. Chem. Phys. Discuss., 9, 81-134, doi:10.5194/acpd-981-2009, 2009.

Sanhueza, E., Holzinger, R., Donoso, L., Santana, M., Fernandez, E., and Romero, J.: Volatile organic compounds in the atmosphere of La Gran Sabana. I: Concentrations and atmospheric chemistry, Interciencia, 26, 597-605, 2001.

Sanhueza, E., Holzinger, R., Kleiss, B., Donoso, L., and Crutzen, P. J.: New insights in the global cycle of acetonitrile: release from theocean and dry deposition in the tropical savanna of Venezuela, Atmos. Chem. Phys., 4, 275-280, doi:10.5194/acp-4-275-2004, 2004.

Sanz, M. J., Calatayud, V., and Calvo, E.: Spatial pattern of ozone injury in Aleppo pine related to air pollution dynamics in a coastal-mountain region of eastern Spain, Environ. Pollut., 108, 239-247, 2000. 
Seco, R., Peñuelas, J., and Filella, I.: Short-chain oxygenated VOCs: Emission and uptake by plants and atmospheric sources, sinks, and concentrations, Atmos. Environ., 41, 2477-2499, doi:10.1016/j.atmosenv.2006.11.029, 2007.

Seco, R., Peñuelas, J., and Filella, I.: Formaldehyde emission and uptake by Mediterranean trees Quercus ilex and Pinus halepensis, Atmos. Environ., 42, 7907-7914, doi:10.1016/j.atmosenv.2008.07.006, 2008.

Seco, R., Filella, I., Llusià, J., and Peñuelas, J.: Methanol as a signal triggering isoprenoid emissions and photosynthetic performance in Quercus ilex, Acta Physiol. Plant., 33, 2413-2422, doi:10.1007/s11738-011-0782-0, 2011.

Sillman, S.: The relation between ozone, $\mathrm{NO}_{\mathrm{x}}$ and hydrocarbons in urban and polluted rural environments, Atmos. Environ., 33, 1821-1845, 1999.

Singh, H. B., Salas, L. J., Chatfield, R. B., Czech, E., Fried, A., Walega, J., Evans, M. J., Field, B. D., Jacob, D. J., Blake, D., Heikes, B., Talbot, R., Sachse, G., Crawford, J. H., Avery, M. A., Sandholm, S., and Fuelberg, H.: Analysis of the atmospheric distribution, sources, and sinks of oxygenated volatile organic chemicals based on measurements over the Pacific during TRACE-P, J. Geophys. Res., 109, D15S07, doi:10.1029/2003JD003883, 2004.

Singsaas, E. L. and Sharkey, T. D.: The regulation of isoprene emission responses to rapid leaf temperature fluctuations, Plant Cell Environ., 21, 1181-1188, 1998.

Spirig, C., Neftel, A., Ammann, C., Dommen, J., Grabmer, W., Thielmann, A., Schaub, A., Beauchamp, J., Wisthaler, A., and Hansel, A.: Eddy covariance flux measurements of biogenic VOCs during ECHO 2003 using proton transfer reaction mass spectrometry, Atmos. Chem. Phys., 5, 465-481, doi:10.5194/acp-5-465-2005, 2005.

Staudt, M., Rambal, S., Joffre, R., and Kesselmeier, J.: Impact of drought on seasonal monoterpene emissions from Quercus ilex in southern France, J. Geophys. Res.-Atmos., 107, 4602, doi:10.1029/2001JD002043, 2002.
Steinbrecher, R., Klauer, M., Hauff, K., Stockwell, W. R., Jaeschke, W., Dietrich, T., and Herbert, F.: Biogenic and anthropogenic fluxes of non-methane hydrocarbons over an urban-impacted forest, Frankfurter Stadtwald, Germany, Atmos. Environ., 34, 3779-3788, 2000.

Terradas, J.: Holm oak and holm oak forest: an introduction, in: Ecology of Mediterranean evergreen oak forests, edited by: Rodà, F., Retana, J., Gracia, C. A., and Bellot, J., Springer, Berlin, 3-14, 1999.

Tunved, P., Hansson, H. C., Kerminen, V. M., Strom, J., Dal Maso, M., Lihavainen, H., Viisanen, Y., Aalto, P. P., Komppula, M., and Kulmala, M.: High natural aerosol loading over boreal forests, Science, 312, 261-263, 2006.

Velikova, V., Pinelli, P., Pasqualini, S., Reale, L., Ferranti, F., and Loreto, F.: Isoprene decreases the concentration of nitric oxide in leaves exposed to elevated ozone, New Phytol., 166, 419-426, 2005 .

Warneke, C., Luxembourg, S. L., de Gouw, J. A., Rinne, H. J. I., Guenther, A., and Fall, R.: Disjunct eddy covariance measurements of oxygenated volatile organic compounds fluxes from an alfalfa field before and after cutting, J. Geophys. Res., 107, 4067-4067, 2002.

White, M. L., Russo, R. S., Zhou, Y., Ambrose, J. L., Haase, K., Frinak, E. K., Varner, R. K., Wingenter, O. W., Mao, H., Talbot, R., and Sive, B. C.: Are biogenic emissions a significant source of summertime atmospheric toluene in the rural Northeastern United States?, Atmos. Chem. Phys., 9, 81-92, doi:10.5194/acp9-81-2009, 2009.

Wright, G. A. and Schiestl, F. P.: The evolution of floral scent: the influence of olfactory learning by insect pollinators on the honest signalling of floral rewards, Funct. Ecol., 23, 841-851, 2009.

Zhao, J. and Zhang, R. Y.: Proton transfer reaction rate constants between hydronium ion $\left(\mathrm{H}_{3} \mathrm{O}^{+}\right)$and volatile organic compounds, Atmos. Environ., 38, 2177-2185, 2004.

Ziomas, I. C.: The Mediterranean Campaign of Photochemical Tracers Transport and chemical evolution (MEDCAPHOTTRACE): An outline, Atmos. Environ., 32, 2045-2053, 1998. 